\title{
Chemical and Metagenomic Studies of the Lethal Black Band Disease of Corals Reveal Two Broadly Distributed, Redox-Sensitive Mixed Polyketide/Peptide Macrocycles
}

\author{
Sarath P. Gunasekera, ${ }^{\dagger}$ Julie L. Meyer, ${ }^{\ddagger}$ Yousong Ding, ${ }^{\S}{ }^{\circledR}$ Khalil A. Abboud, ${ }^{\perp}$ Danmeng Luo, ${ }^{\S}$
} Justin E. Campbell, ${ }^{\dagger}$ Alexander Angerhofer, ${ }^{\perp}{ }^{\perp}$ Justin L. Goodsell, ${ }^{\perp}$ Laurie J. Raymundo, Junyang Liu, Tao Ye, ${ }^{\# \odot ~ H e n d r i k ~ L u e s c h, ~}{ }^{\S \odot}$ Max Teplitski, ${ }^{\dagger}{ }^{\ddagger}$ and Valerie J. Paul ${ }^{*}, \dagger \odot$

${ }^{\dagger}$ Smithsonian Marine Station, Ft. Pierce, Florida 34949, United States

${ }^{\ddagger}$ Soil and Water Sciences Department, University of Florida-Institute of Food and Agricultural Sciences, Gainesville, Florida 32611, United States

${ }^{\S}$ Department of Medicinal Chemistry and Center for Natural Products, Drug Discovery and Development, University of Florida, Gainesville, Florida 32610, United States

${ }^{\perp}$ Department of Chemistry, University of Florida, Gainesville, Florida 32611, United States

"University of Guam Marine Laboratory, Mangilao, GU 96923, United States

${ }^{\#}$ State Key Laboratory of Chemical Oncogenomics, School of Chemical Biology and Biotechnology, Peking University Shenzhen Graduate School, Xili, Nanshan District, Shenzhen, 518055, People's Republic of China

\section{Supporting Information}

ABSTRACT: Black band disease (BBD), a lethal, polymicrobial disease consortium dominated by the cyanobacterium Roseofilum reptotaenium, kills many species of corals worldwide. To uncover chemical signals or cytotoxins that could be important in proliferation of Roseofilum and the BBD layer, we examined the secondary metabolites present in geographically diverse collections of $\mathrm{BBD}$ from Caribbean and Pacific coral reefs. Looekeyolide A (1), a 20-membered macrocyclic compound formed by a 16-carbon polyketide chain, 2deamino-2-hydroxymethionine, and D-leucine, and its autoxidation product looekeyolide B (2) were extracted as major compounds $\left(\sim 1 \mathrm{mg} \mathrm{g}^{-1}\right.$ dry wt) from more than a dozen
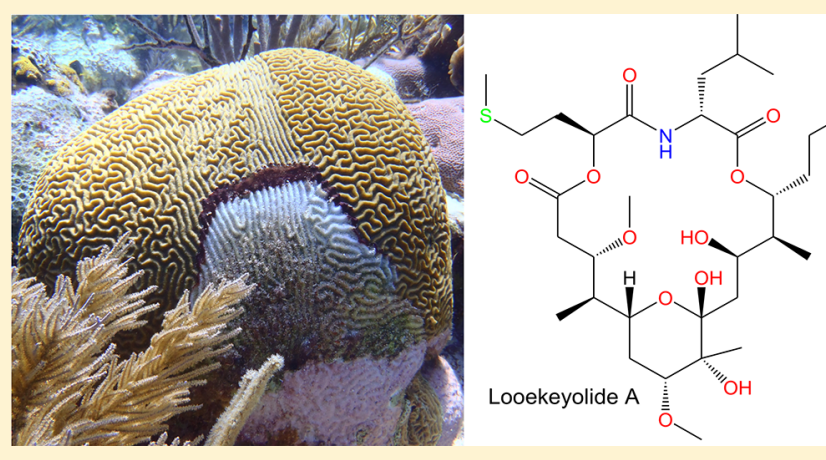
field-collected BBD samples. Looekeyolides A and B were also produced by a nonaxenic $R$. reptotaenium culture under laboratory conditions at similar concentrations. $R$. reptotaenium genomes that were constructed from four different metagenomic data sets contained a unique nonribosomal peptide/polyketide biosynthetic cluster that is likely responsible for the biosynthesis of the looekeyolides. Looekeyolide $\mathrm{A}$, which readily oxidizes to looekeyolide $\mathrm{B}$, may play a biological role in reducing $\mathrm{H}_{2} \mathrm{O}_{2}$ and other reactive oxygen species that could occur in the BBD layer as it overgrows and destroys coral tissue.

$\mathrm{B}$ lack band disease (BBD) is a globally distributed coral disease that kills many species of corals, especially large, reef-building scleractinians, and it has been observed on coral reefs since at least the 1970 s. $^{1-5} \mathrm{BBD}$ is easily recognized by the appearance of a dense dark purple or black band, which is the visible accumulation of phycoerythrin-rich filamentous cyanobacteria separating live coral tissue from recently killed white coral skeleton (Figure 1). ${ }^{5-7}$ Roseofilum reptotaenium is the dominant cyanobacterium within the $\mathrm{BBD}$ disease consortium. ${ }^{6}$ Strains of Roseofilum have been cultivated in the laboratory, but like many other filamentous cyanobacteria, Roseofilum cannot be fully isolated, only grown in nonaxenic, unicyanobacterial cultures. ${ }^{6}$ Recent work discovered that Roseofilum is an uncommon, but widespread member of healthy coral microbiomes, implying that growth of Roseofilum is constrained in healthy tissue until undefined environmental or host-derived restrictions are removed. ${ }^{8}$ When conditions are favorable for the growth of Roseofilum, it creates a migrating band, which dramatically alters microbial community structure $^{8}$ and kills host tissue underneath the band. ${ }^{1-5}$

To better understand the mechanisms through which $R$. reptotaenium proliferates and creates a new environment on the surface of corals during $\mathrm{BBD}$, we examined the major secondary metabolites present in the black band layer in situ in geographically diverse collections, with a particular focus on

Received: September 22, 2018

Published: January 13, 2019 

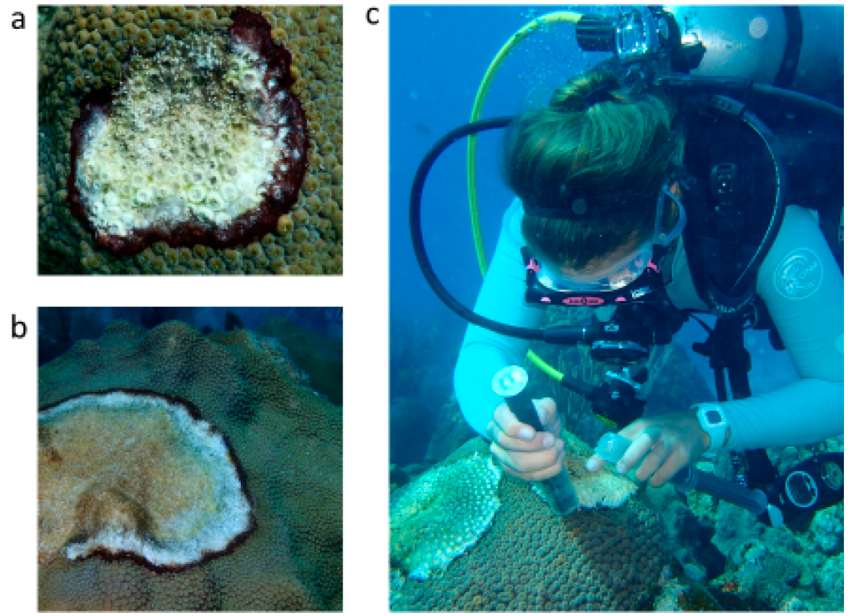

Figure 1. Photographs of the black band disease (BBD) affecting different coral species. (a) BBD on Montastraea cavernosa in the Florida Keys. (b) BBD on Orbicella faveolata in the Florida Keys. (c) Collecting BBD from $M$. cavernosa in $60 \mathrm{~mL}$ syringes at Looe Key Reef, Florida Keys.

their possible natural functions in the proliferation of the disease. We previously reported the presence of lyngbic acid 9 as a major metabolite in collections of BBD and showed that it inhibited quorum sensing among Vibrio bacteria present in corals. $^{8}$ Herein, we describe the looekeyolides A (1) and B (2) isolated from the lipophilic extracts of $\mathrm{BBD}$, characterize their unique structures and the biosynthetic gene cluster putatively responsible for their biosynthesis, and shed light on natural functions of these compounds. Looekeyolides A and B are named after the primary collection site of BBD for this study, Looe Key reef in the Florida Keys, although they occurred in all samples of BBD examined. The redox-sensitivity of looekeyolide A provides insights into how BBD layers can overgrow live coral tissue and overcome the production of reactive oxygen species by the coral holobiont.

\section{RESULTS AND DISCUSSION}

Characterization of the Major Secondary Metabolites in BBD. To uncover the secondary metabolites that are biologically important and dominant in BBD, we took a twopronged approach: isolating and characterizing the dominant products in the black band layer and the $R$ reptotaenium culture and identifying the biosynthetic cluster predicted to produce these metabolites. Low-resolution LCMS indicated two dominant peaks in all extracts of field-collected BBD and in the Roseofilum culture (Figure 2). Two macrocyclic metabolites, looekeyolide A (1) and its oxidized product, looekeyolide B (2), were identified from the lipophilic extracts of 13 Caribbean and Pacific BBD samples, cultured $R$. reptotaenium, and in re-collections from Florida and Belize locations. Looekeyolide B $\left([\mathrm{M}+\mathrm{Na}]^{+}=m / z\right.$ 702) was observed at a retention time of $\sim 8.7 \mathrm{~min}$ and looekeyolide $\mathrm{A}$ $\left([\mathrm{M}+\mathrm{Na}]^{+}=m / z 686\right)$ at $\sim 11.6 \mathrm{~min}$ in the LCMS data (Figure 2).

Looekeyolide B (2), the more stable of the two compounds, was obtained as a white, amorphous powder. HRESI/APCIMS supported the molecular formula of $\mathrm{C}_{32} \mathrm{H}_{57} \mathrm{NO}_{12} \mathrm{~S}$. The IR spectrum displayed absorption bands at 1736 and $1679 \mathrm{~cm}^{-1}$, indicating the presence of ester and amide functionalities. A strong broad absorption band at $3400 \mathrm{~cm}^{-1}$ suggested the
Chart 1

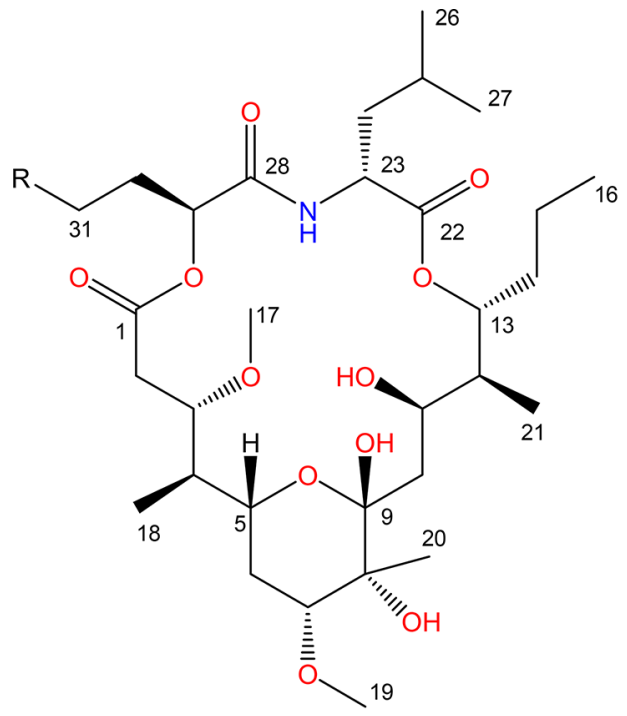

Looekeyolide A (1), $\mathrm{R}=\mathrm{S}-\mathrm{CH}_{3}$ Looekeyolide B (2), $\mathrm{R}=\mathrm{S}(\mathrm{O})-\mathrm{CH}_{3}$ Des-thiomethyllooekeyolide $\mathrm{A}(3), \mathrm{R}=\mathrm{H}$

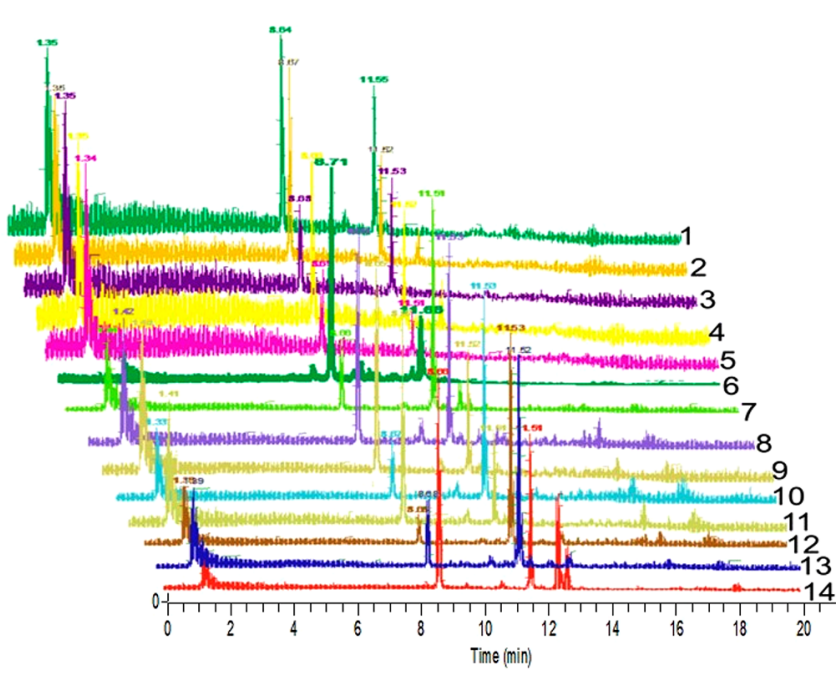

Figure 2. LCMS analysis of BBD collections. Low-resolution LCMS data showing two prominent peaks (looekeyolide B at $\sim 8.6-8.7 \mathrm{~min}$ and looekeyolide A at $\sim 11.5-11.6$ min.) in extracts of field-collected BBD and cultured Roseofilum reptotaenium: (1) Montastraea cavernosa, Belize, (2-5) M. cavernosa, Florida, (6) Goniopora fruticosa, Guam, (7) Pseudodiploria strigosa, Belize, $(8,9)$ P. strigosa, Honduras, (10) P. clivosa, Belize, (11) P. strigosa, Honduras, (12) O. annularis, Belize, (13) O. faveolata, Belize, (14) Roseofilum reptotaenium culture.

presence of several hydroxy groups in the molecule. The ${ }^{1} \mathrm{H}$ and ${ }^{13} \mathrm{C}$ NMR data were indicative of one $\alpha$-amino acid, one $\alpha$ hydroxy acid, and one highly substituted 16-carbon PK chain in the molecule (Table 1).

Interpretation of DQF COSY, edited HSQC, and HMBC data for C-22 to C-27 identified the amino acid as leucine (Supporting Information, pp S5-S10). The doubling of the ${ }^{13} \mathrm{C}$ signals from $\mathrm{C}-28$ to $\mathrm{C}-32$ and the doubling of ${ }^{1} \mathrm{H}$ signals appeared as overlapping multiplets from $\mathrm{H}-29$ to $\mathrm{H}-31$, and the split methyl signal $\mathrm{H}_{3}-32\left(\delta_{\mathrm{H}} 2.521,2.520 ; \delta_{\mathrm{C}} 39.0,38.9\right)$ together with the presence of a sulfur atom in the molecular 
Chart 2. Perspective Drawing of the X-ray Model of desThiomethyllooekeyolide A (3)

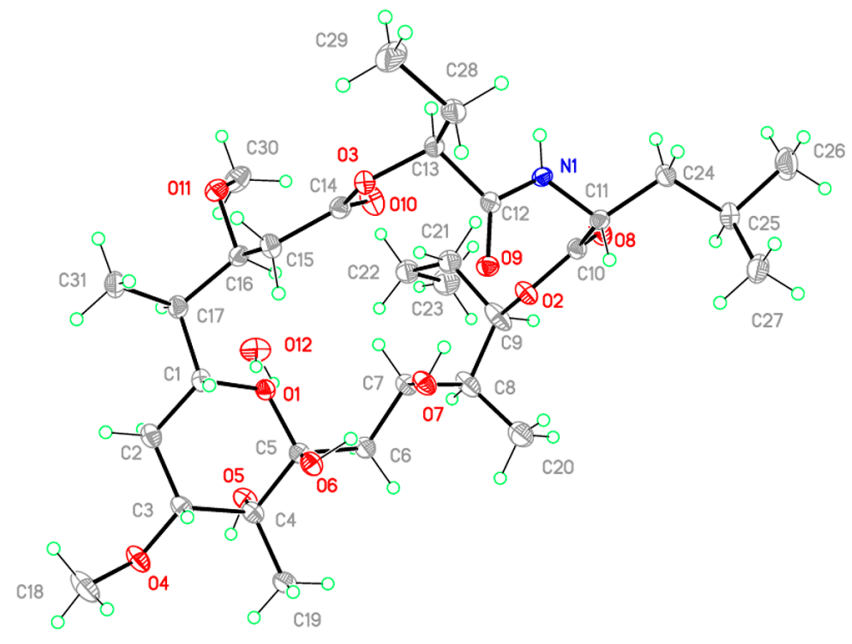

formula suggested the presence of a hydroxymethionine sulfoxide residue in the molecule. ${ }^{10}$ The COSY spectrum indicated coupling of hydroxymethine $\mathrm{H}-29\left(\delta_{\mathrm{H}} 4.91, \delta_{\mathrm{C}} 73.9 /\right.$ 73.4) to methylene protons $\mathrm{H}_{2}-30\left(\delta_{\mathrm{H}} 2.15, \delta_{\mathrm{C}} 26.0,25.6\right)$ and then in turn to $\mathrm{H}_{2}-31\left(\delta_{\mathrm{H}} 2.85,2.71, \delta_{\mathrm{C}} 50.3 .50 .0\right)$. The HMBC spectrum showed correlations of the methylene $\mathrm{H}_{2}-31$ to carbon signal C-32 $\left(\delta_{\mathrm{C}} 39.0 / 38.9\right)$ and of the methyl split singlet $-\mathrm{S}-32-\mathrm{H}_{3}\left(\delta_{\mathrm{H}} 2.521 / 2.520\right)$ in turn to C-31 $\left(\delta_{\mathrm{C}} 50.3\right.$, $50.0)$, thus confirming the presence of a 2-deamino-2hydroxymethionine sulfoxide $[\operatorname{Met}(\mathrm{O})]$ residue in the molecule. Following the interpretation of DQF COSY, edited $\mathrm{HSQC}$, and ${ }^{13} \mathrm{C}$ experiments, the remaining ${ }^{1} \mathrm{H}$ signals were assignable to two partial structures ( $\mathrm{C}-2$ to $\mathrm{C}-7$ and $\mathrm{C}-10$ to $\mathrm{C}$ 16), two O-Me groups $\left(\mathrm{H}-17, \delta_{\mathrm{H}} 3.27, \mathrm{H}-19, \delta_{\mathrm{H}} 3.35\right)$, three hydroxy groups $\left(\mathrm{OH}-8, \delta_{\mathrm{H}} 2.36 ; \mathrm{OH}-9, \delta_{\mathrm{H}} 6.16\right.$, OH-11, $\delta_{\mathrm{H}}$ 3.76), the remaining ${ }^{13} \mathrm{C}$ signals to two nonprotonated carbons $\left(\mathrm{C}-8, \delta_{\mathrm{C}} 74.0\right.$; C-9, $\left.\delta_{\mathrm{C}} 101.8\right)$, and one ester carbonyl group (C$\left.1, \delta_{\mathrm{C}} 173.0\right)$ (Table 1$)$. HMBC correlations from $\mathrm{H}-3\left(\delta_{\mathrm{H}}\right.$

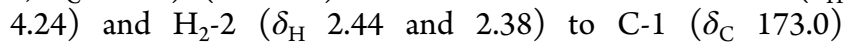
connected the remaining ester carbonyl. Similarly, the HMBC correlations from $\mathrm{H}-17\left(\delta_{\mathrm{H}} 3.27\right)$ to $\mathrm{C}-3$ and $\mathrm{H}-19\left(\delta_{\mathrm{H}} 3.35\right)$ to $\mathrm{C}-7\left(\delta_{\mathrm{C}} 79.5\right)$ connected the two OMe groups to the C-3 and $\mathrm{C}-7$ positions. $\mathrm{HMBC}$ correlations connected the $\mathrm{H}_{3}-18$ methyl $\left(\delta_{\mathrm{H}} 0.80\right)$ to C-3 $\left(\delta_{\mathrm{C}} 77.0\right)$ and C-5 $\left(\delta_{\mathrm{C}} 70.1\right)$. These data connected the methyl group, two methoxy groups, and the carbonyl group to the $\mathrm{C}-2$ to $\mathrm{C}-7$ partial structure. $\mathrm{HMBC}$ correlations indicated $\mathrm{H}_{3}-20$ to $\mathrm{C}-7\left(\delta_{\mathrm{C}} 79.5\right)$ and C-8 $\left(\delta_{\mathrm{C}}\right.$ $74.0), \mathrm{OH}-9\left(\delta_{\mathrm{H}} 6.16\right)$ to $\mathrm{C}-8, \mathrm{C}-9$, and C-10 $\left(\delta_{\mathrm{C}} 37.0\right)$, and $\mathrm{H}_{2}-6\left(\delta_{\mathrm{H}} 2.08,1.28\right)$ to $\mathrm{C}-5$ and $\mathrm{C}-7$. This information connected the partial structure $\mathrm{C}-2$ to $\mathrm{C}-7$ to partial structure C-10 to C-16 and thus established the planar structure for the substituted 16-carbon polyketide chain moiety. Strong NOE correlations between the H-5 oxymethine $\left(\delta_{\mathrm{H}} 3.58\right)$ and the C$9\left(\delta_{\mathrm{C}} 101.8\right)$ anomeric $\mathrm{OH}\left(\delta_{\mathrm{H}} 6.16\right)$ group suggested the presence of a pyrano ring system within the chain. An HMBC correlation from the leucine $\mathrm{NH}$ to the $\mathrm{C}-28$ carbonyl carbon of the hydroxymethione connected the leucine to the hydroxymethione group. An HMBC correlation between the $\mathrm{H}-13$ of the $\mathrm{C}_{16}$ polyketide chain and the C-22 carbonyl of leucine connected these two residues by an ester linkage. Similarly, the HMBC correlation between H-29 of the hydroxymethine and the C-1 carbonyl of the PK chain connected these two residues by an ester linkage. These data established the planar macrocyclic structure for looekeyolide B (2).

Looekeyolide A (1) was obtained as a white solid (HRESI/ APCIMS $m / z$ 686.3528 $\left.[\mathrm{M}+\mathrm{Na}]^{+}\right)$. HRESIMS analysis indicated the difference of one oxygen atom in the molecular formulas of 1 and 2 . The ${ }^{1} \mathrm{H}$ and ${ }^{13} \mathrm{C}$ NMR spectral data of 1 were very similar to those of $\mathbf{2}$ (Supporting Information pp S3, S4). The characteristic doubling of signals for the protons and carbons in the vicinity of the hydroxy acid in 2 were absent in the ${ }^{1} \mathrm{H}$ and ${ }^{13} \mathrm{C}$ NMR spectra of $\mathbf{1}$, indicating the absence of a sulfoxide group in $\mathbf{1}$. We noticed that looekeyolide $\mathrm{A}$ undergoes partial autoxidation to looekeyolide B during the isolation and HPLC separation process. This information together with the analysis of COSY, HSQC, and HMBC data with the NMR data of $\mathbf{2}$ (Table 1) confirmed the structure of looekeyolide A (1) as $S$-deoxylooekeyolide B.

The absolute configuration of the leucine residue was determined by chiral-phase HPLC analysis, comparing the amino acid content in the acid hydrolysate with standard Dand L-leucine. Retention times established the D-configuration for leucine. Looekeyolide B was subjected to desulfurization with Raney-Ni to give des-thiomethyllooekeyolide A (3). The desulfurization converted the hydroxy $\operatorname{Met}(\mathrm{O})$ in looekeyolide $\mathrm{B}$ to 2-hydroxybutyric acid. The acid hydrolysate of desthiomethyllooekeyolide $\mathrm{A}$ was used to determine the configuration of 2-hydroxybutyric acid, which determined the absolute configuration of 2-deamino-2-hydroxymethionine in looekeyolide A and 2-deamino-2-hydroxymethionine sulfoxide in looekeyolide $\mathrm{B}$. The retention time indicated the presence of (S)-2-hydroxybutyric acid.

Compound $\mathbf{1}$ is likely the natural product produced by the cyanobacterium and was stable only under helium gas and in the presence of trace fatty acid impurities. Looekeyolide B (2) is the autoxidized product and is stable under normal laboratory conditions, and although it forms during extraction and purification, it may also occur in the BBD layer through natural oxidation-reduction processes. As the stable looekeyolide B (2) occurs as a mixture of $R$ and $S$ sulfoxide diastereomers, a semisynthetic desulfurized analogue, desthiomethyllooekeyolide A (3), was prepared and crystallized for configurational analysis. A crystal of des-thiomethyllooekeyolide A was used in X-ray crystallography studies to establish the relative stereostructure of the highly substituted cyclized molecule. The crystal structure has been deposited in the Cambridge Crystallographic Data Centre (CCDC 1492584). Because the absolute configuration of leucine and hydroxy acid units in the molecule was determined by chiralphase HPLC analysis, applying the absolute configurations of (S)-2-hydroxybutyric acid and D-leucine to the X-ray relative stereostructure established the absolute configuration of all stereogenic centers of des-thiomethyllooekeyolide A. This information was extended to determine the absolute configuration of all stereogenic centers of the related looekeyolides A and B.

The structural assignment of $\mathbf{3}$ was confirmed by total chemical synthesis, which included a concise assembly of three building blocks to afford a macrocyclic precursor and subsequent dual macrolactonization/pyran-hemiketal formation (Figure 3). As shown, des-thiomethyllooekeyolide A was obtained from the corresponding linear seco acid precursor by a macrocyclization reaction followed by removal of protecting groups. The linear seco acid precursor was assembled from a polypropionic acid segment, an amino acid chloride, and a 
Table 1. NMR Spectroscopic Data for Looekeyolide B (2) in $\mathrm{CD}_{3} \mathrm{CN}\left({ }^{1} \mathrm{H} 600 \mathrm{MHz},{ }^{13} \mathrm{C} 151 \mathrm{MHz}\right)$

\begin{tabular}{|c|c|c|c|c|c|}
\hline position & $\delta_{\mathrm{C}}$ mult. & $\delta_{\mathrm{H}}(J$ in $\mathrm{Hz})$ & $\operatorname{cosY}^{a}$ & $\mathrm{HMBC}^{b}$ & NOESY \\
\hline 1 & 173.0, C & & & $2 a, 2 b, 3,29$ & \\
\hline $2 \mathrm{a}$ & $33.4, \mathrm{CH}_{2}$ & $2.44, \mathrm{~d}(-12.0)$ & $2 b, 3$ & 3,4 & $5,2 b$ \\
\hline $2 b$ & & $2.38, \mathrm{dd}(-12.0,9.6)$ & $2 a, 3$ & & $2 \mathrm{a}$ \\
\hline 3 & 77.0, $\mathrm{CH}$ & $4.24, \mathrm{dd}(9.6,4.2)$ & $2 a, 2 b, 4$ & $2 a, 2 b, 4,18$ & $4,11,17$ \\
\hline 4 & $38.3, \mathrm{CH}$ & $2.11, \mathrm{~m}$ & $3,5,18$ & $5,6 a, 6 b$ & $3,17,18$ \\
\hline 5 & $70.1, \mathrm{CH}$ & 3.58 , ddd $(10.8,10.8,1.8)$ & $4,6 a, 6 b$ & $4,6,18$ & $2 a, 6 a, 18$ \\
\hline $6 a$ & $31.2, \mathrm{CH}_{2}$ & $2.06, \mathrm{~m}$ & $5,6 b, 7$ & & $5,6 b, 7,19$ \\
\hline $6 b$ & & $1.28, \mathrm{~m}$ & $5,6 a, 7$ & & $6 a$ \\
\hline 7 & 79.5, $\mathrm{CH}$ & 3.35 , dd $(11.4,3.3)$ & $6 a, 6 b$ & $5,6 a, 6 b, 20$ & $6 a, 20$ \\
\hline 8 & 74.0, C & & & $6 \mathrm{a}, 6 \mathrm{~b}, 8-\mathrm{OH} 9-\mathrm{OH}, 20$ & \\
\hline $8-\mathrm{OH}$ & & $2.36, \mathrm{~s}$ & & & \\
\hline 9 & $101.8, \mathrm{C}$ & & & 8-OH, 9-OH 11, 20 & \\
\hline $9-\mathrm{OH}$ & & $6.16, \mathrm{~s}$ & & & $11-\mathrm{OH}, 10 \mathrm{a}, 20$ \\
\hline $10 \mathrm{a}$ & 37.0, $\mathrm{CH}_{2}$ & 1.85 , dd $(-14.4,12.0)$ & $10 b, 11$ & 9-OH, 11-H 11-OH, 12-H & $10 b, 20,21$ \\
\hline $10 b$ & & $1.57, \mathrm{~d}(-14.4)$ & $10 a, 11$ & & $10 \mathrm{a}$ \\
\hline 11 & $66.4, \mathrm{CH}$ & $4.62, \mathrm{~d}(11.4)$ & $10 a, 10 b$ & 10a, 11-OH 13, 21 & $3,11-\mathrm{OH}, 1210 \mathrm{a}, 14 \mathrm{a}$ \\
\hline $11-\mathrm{OH}$ & & 3.76 , brs & & & $9-\mathrm{OH}, 21$ \\
\hline 12 & $42.2, \mathrm{CH}$ & $1.47, \mathrm{~m}$ & 13,21 & $10 \mathrm{a}, 10 \mathrm{~b}, 13,21$ & 13,21 \\
\hline 13 & $80.3, \mathrm{CH}$ & $4.90, \mathrm{~m}$ & $12,14 a, 14 b$ & 11,21 & 12,21 \\
\hline $14 \mathrm{a}$ & $34.8, \mathrm{CH}_{2}$ & $2.06, \mathrm{~m}$ & $13,14 b, 15 a, 15 b$ & 13,16 & $14 \mathrm{~b}$ \\
\hline $14 b$ & & $1.49, \mathrm{~m}$ & $13,14 a, 15 a, 15 b$ & & $14 \mathrm{a}$ \\
\hline $15 \mathrm{a}$ & 19.9, $\mathrm{CH}_{2}$ & $1.25, \mathrm{~m}$ & $14 a, 14 b, 15 b, 16$ & 13,16 & $15 b, 16$ \\
\hline $15 b$ & & $1.17, \mathrm{~m}$ & $14 a, 14 b, 15 a, 16$ & & $15 a, 16$ \\
\hline 16 & $14.3, \mathrm{CH}_{3}$ & $0.89, \mathrm{t}(7.2)$ & $15 a, 15 b$ & $14 a, 14 b$ & \\
\hline 17 & $57.2, \mathrm{OCH}_{3}$ & $3.27, \mathrm{~s}$ & & 3 & 3,4 \\
\hline 18 & $9.8, \mathrm{CH}_{3}$ & $0.80, \mathrm{~d}(6.8)$ & 4 & $3,4,5$ & 4,5 \\
\hline 19 & $57.5, \mathrm{OCH}_{3}$ & $3.35, \mathrm{~s}$ & & 7 & 6 \\
\hline 20 & $20.3, \mathrm{CH}_{3}$ & $1.19, \mathrm{~s}$ & & $7,8-\mathrm{OH}$ & $7,10 \mathrm{a}$ \\
\hline 21 & $11.9, \mathrm{CH}_{3}$ & $0.91, \mathrm{~d}(6.6)$ & 12 & $11,12,13$ & $13,10 \mathrm{a}, 11-\mathrm{OH}$ \\
\hline 22 & $171.9, \mathrm{C}$ & & & 13,23 & \\
\hline 23 & $50.3, \mathrm{CH}$ & $4.50, \mathrm{~m}$ & $23-\mathrm{NH}, 24 \mathrm{a}, 24 \mathrm{~b}$ & $23-\mathrm{NH}, 24 \mathrm{a}, 24 \mathrm{~b}$ & $24 a, 26$ \\
\hline \multirow[t]{2}{*}{ 23-NH } & & $7.36, \mathrm{~d}(9.0)$ & 23 & & 29 \\
\hline & & $7.24, \mathrm{~d}(9.0)$ & 23 & & \\
\hline $24 \mathrm{a}$ & $38.3, \mathrm{CH}_{2}$ & $1.70, \mathrm{~m}$ & $23,24 b, 25$ & $23,26,27$ & $23,24 b$ \\
\hline $24 b$ & & $1.59, \mathrm{~m}$ & $23,24 a, 25$ & & $24 \mathrm{a}$ \\
\hline 25 & $25.4, \mathrm{CH}$ & $1.66, \mathrm{~m}$ & $24 a, 24 b, 26,27$ & $24 a, 24 b, 26,27$ & 26,27 \\
\hline 26 & 21.1, $\mathrm{CH}_{3}$ & $0.83, \mathrm{~d}(6.6)$ & 25 & $24 a, 24 b, 27$ & 23,25 \\
\hline 27 & 23.4, $\mathrm{CH}_{3}$ & $0.93, \mathrm{~d}(6.6)$ & 25 & $24 a, 24 b, 26$ & 25 \\
\hline 28 & $172.6,172.5, \mathrm{C}$ & & & 23-NH, 30 & \\
\hline 29 & 73.9, 73.4, CH & 4.91, m & 30 & $31 a, 31 b$ & 30 \\
\hline 30 & $26.0,25.6, \mathrm{CH}_{2}$ & $2.15, \mathrm{~m}$ & $29,31 a, 31 b$ & $29,31 a, 31 b$ & 29 \\
\hline $31 \mathrm{a}$ & $50.3,50.0, \mathrm{CH}_{2}$ & $2.85, \mathrm{~m}$ & $30,31 b$ & 29,32 & $31 b$ \\
\hline $31 b$ & & $2.71, \mathrm{~m}$ & $30,31 a$ & & $31 \mathrm{a}$ \\
\hline 32 & $39.0,38.9, \mathrm{CH}_{3}$ & $2.521, \mathrm{~s}$ & & $31 a, 31 b$ & \\
\hline & & $2.520, \mathrm{~s}$ & & & \\
\hline
\end{tabular}

${ }^{a}$ COSY and NOESY correlations are from proton(s) stated to the indicated protons. ${ }^{b} \mathrm{HMBC}$ correlations are from proton(s) stated to the indicated carbons.

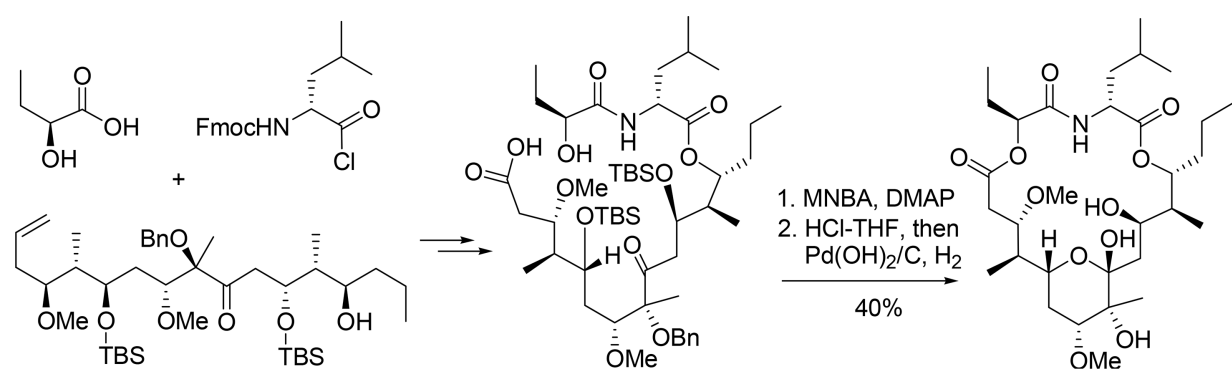

Figure 3. Synthesis scheme for des-thiomethyllooekeyolide A (3). 


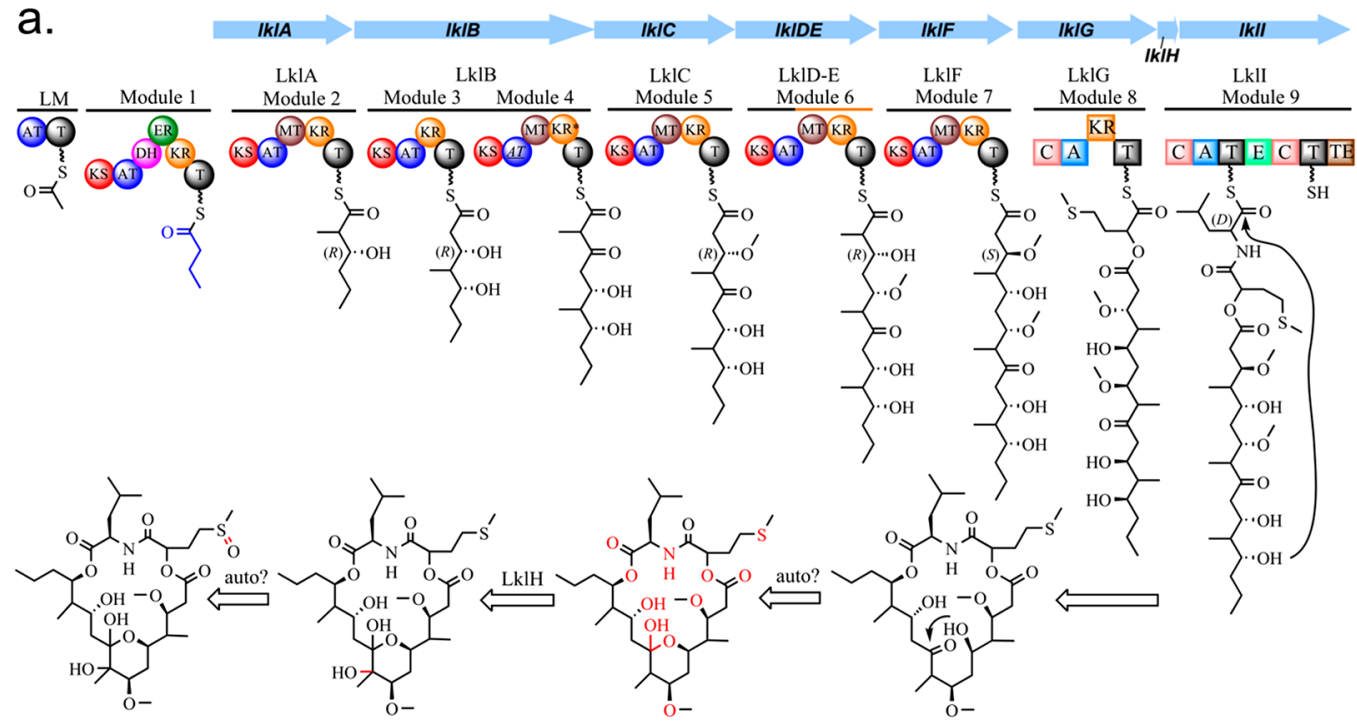

\section{b. AT domains}

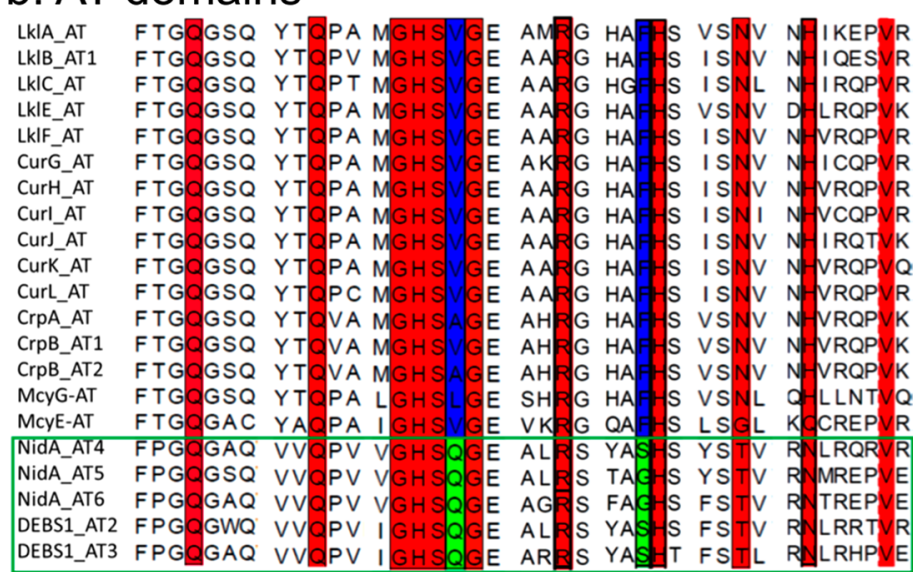

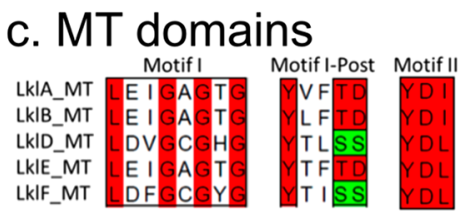

\section{d. KR domains}

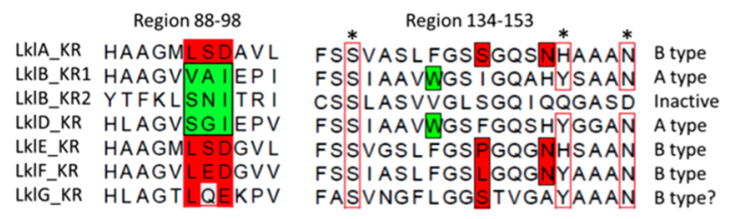

Figure 4. Looekeyolide biosynthetic cluster in Roseofilum with proposed biosynthetic pathway. (a) Proposed biosynthetic pathway of looekeyolide A deduced from the identified $l k l$ gene clusters present in four Roseofilum metagenome-assembled genomes from Florida, Belize, and Guam. One loading module and one PKS module (module 1) are missing from all isolated clusters. They are proposed to synthesize a butyrate intermediate from one molecule of acetyl-CoA and one molecule of malonyl-CoA. Alternatively, the loading module may directly activate butyryl-CoA. Stereocenters are labeled based on the prediction of the conserved motifs of KR domains. The second AT domain in LklB is not fully elucidated in four metagenome-assembled genomes. The second KR domain in LklB is predicted to be inactive. The substrate of the LklG A domain is predicted to be a 2-ketoacid and is assumed to be 2-keto-4-(methylthio) butyrate in looekeyolide biosynthesis. (b) Sequence motifs of AT domains from Lkl PKSs, curacin PKSs, cryptophycin PKSs, microcystin PKSs, niddamycin PKSs, and erythromycin PKS. Sequence analysis predicted that all AT domains in Lkl PKSs use malonyl-CoA as their substrates. AT domains from niddamycin PKSs and erythromycin PKS activate methylmalonylCoA. (c) Sequence motifs of MT domains from Lkl PKSs. Sequence analysis predicted that MT domains from LklD and LklF catalyze Omethylation reactions, while all others promote $C$-methylation reactions. (d) Sequence motifs of KR domains from Lkl PKSs and NRPS. KR domains from LklA, LklE, and LklF were predicted to produce a type B hydroxy stereocenter $(R-O H)$, while those from the LklB first module and LklD might produce two $S$ stereocenters with OH groups (type A). The KR domain from LklG (NRPS) was predicted to reduce the 2-keto acid substrate and might also generate an $\mathrm{R}-\mathrm{OH}$ modification. The catalytic residues in these motifs are labeled with asterisks. Two catalytic residues in LklB-KR2 are mutated, making it inactive.

hydroxy acid. Details on the synthesis of 3 will be reported elsewhere.

Biosynthesis of Looekeyolides A and B. One wellconserved nonribosomal peptide (NRP)/polyketide (PK) hybrid biosynthetic cluster, hereafter referred to as the $l k l$ gene cluster, was detected in four Roseofilum metagenomeassembled genomes (MAGs) previously analyzed and is predicted to produce looekeyolide A (Figure 4a). ${ }^{11}$ The $l k l$ gene clusters are publicly available in $\mathrm{IMG}^{12}$ on scaffold IDs 2627864002, 2627864283, 2627863695, and 2627863888. In addition, the $l k l$ gene cluster was detected on a contig (GenBank Accession MLAW01000030) in a Roseofilum MAG from an enrichment culture of BBD isolated from Pavona duerdeni on the central Great Barrier Reef. ${ }^{13}$ The amino acid sequences of $l \mathrm{kl}$ genes from the Caribbean Roseofilum MAGs and the Florida-based Roseofilum culture were $>99 \%$ identical. In contrast, $l \mathrm{kl}$ genes in the Guam Roseofilum MAG ranged from $88 \%$ to $96 \%$ identity with their homologues from the Caribbean Roseofilum MAGs. The core biosynthetic enzymes from the $l k l$ cluster included six PKSs (LklA-F), two NRPSs (LklG and LklI), and one tailoring enzyme (LklH, 2ketoglutarate-Fe(II) dependent dioxygenase) (Figure 4, Supporting Information, pp S17, S18). The specificity of the AT and MT domains and the stereochemistry of the KR 

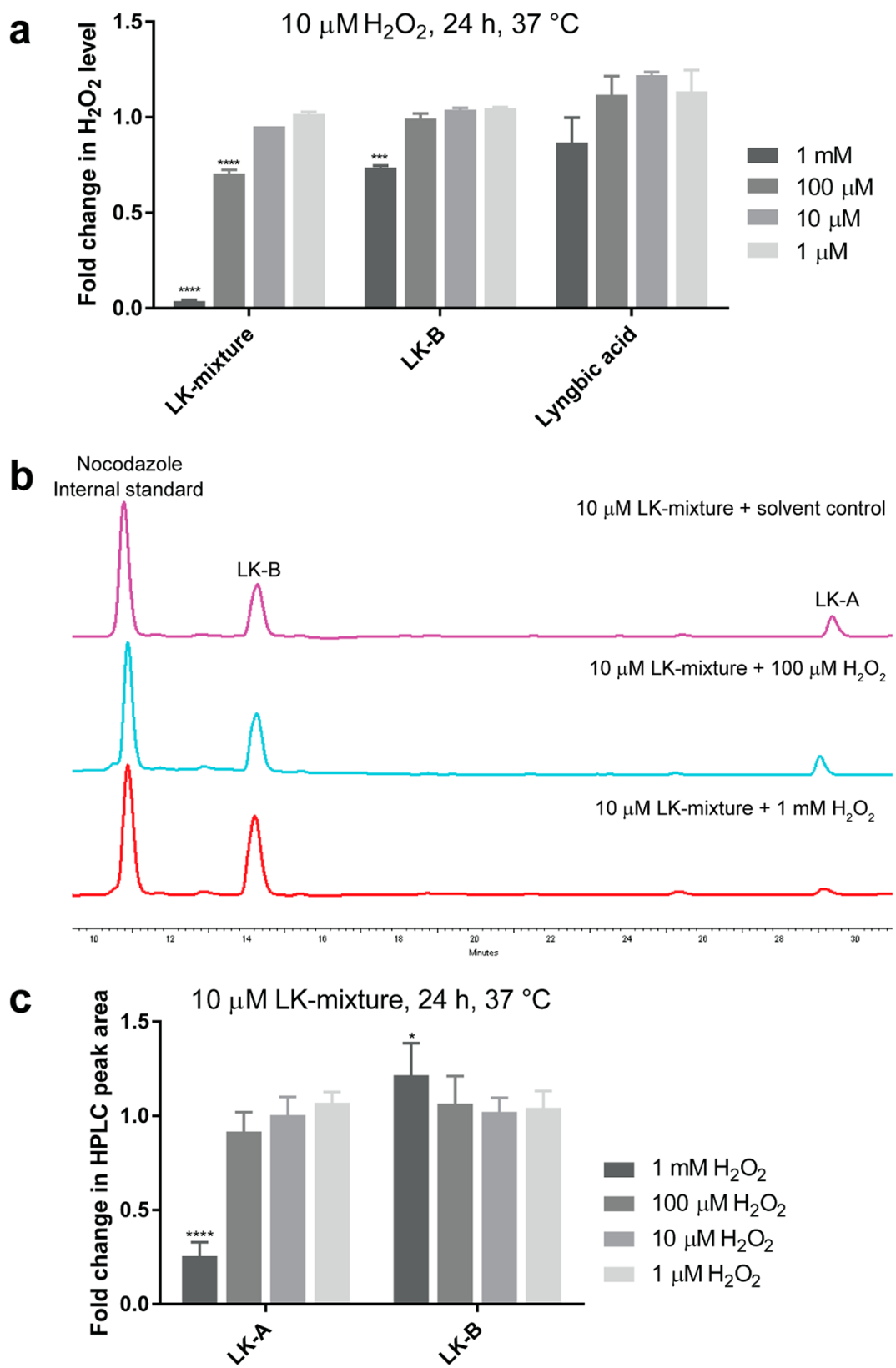

Figure 5. Interactions of looekeyolides with $\mathrm{H}_{2} \mathrm{O}_{2}$. (a) Serial concentrations of a looekeyolide mixture (1-2-lyngbic acid, 1:1:1, estimated by NMR), 2, and lyngbic acid were incubated with $10 \mu \mathrm{M} \mathrm{H}_{2} \mathrm{O}_{2}$ at $37^{\circ} \mathrm{C}$ for $24 \mathrm{~h}$, and the $\mathrm{H}_{2} \mathrm{O}_{2}$ level was measured using the fluorimetric $\mathrm{H}_{2} \mathrm{O}_{2}$ assay kit. The $\mathrm{H}_{2} \mathrm{O}_{2}$ level was significantly reduced when incubating with the looekeyolide mixture, while not affected with either 2 or lyngbic acid, suggesting the ability of 1 to consume $\mathrm{H}_{2} \mathrm{O}_{2}$. Data are presented as mean $\pm \mathrm{SD}, * * * P<0.001$, ****P $P 0.0001$ compared to solvent control using ANOVA and Dunnett's test $(n=2)$. (b) HPLC traces of the looekeyolide mixture after incubating with or without $\mathrm{H}_{2} \mathrm{O}_{2}$ at $37{ }^{\circ} \mathrm{C}$ for 24 h. Nocodazole was used as the internal standard. (c) Fold change in HPLC peak area of $\mathbf{1}$ and $\mathbf{2}$ in each looekeyolide mixture when incubating with or without $\mathrm{H}_{2} \mathrm{O}_{2}$ at $37{ }^{\circ} \mathrm{C}$ for $24 \mathrm{~h}$. By incubating with $\mathrm{H}_{2} \mathrm{O}_{2}$, the peak of 1 was significantly decreased, while the peak of 2 was increased, indicating the conversion of 1 to 2 when reacting with $\mathrm{H}_{2} \mathrm{O}_{2}$. Data are presented as mean $\pm S D$; $* P<0.05$, **** $P<0.0001$ compared to solvent control using ANOVA and Dunnett's test $(n=3)$.

domain were determined by alignment to corresponding domains of characterized biosynthetic clusters of cyanobacteria and others (Figure $4 \mathrm{~b}-\mathrm{d}$ ). Specifically, all AT domains in Lkl PKSs are predicted to be specific toward malonyl-CoA (Figure $4 \mathrm{~b}$ ), while MT domains from LklD and LklF may promote $O$ methylation reactions, with three others for $C$-methylation (Figure 4c). The Lkl PKSs encode six KR domains, including the second KR domain in LklB predicted to be inactive due to the mutations of two key catalytic residues (Figure $4 d$ ). Sequence alignment analysis indicated that the KR domains from LklA, LklE, and LklF produce a type B hydroxyl $R$ stereocenter, while those from the LklB first module and LklD might produce two $S$ stereocenters with $\mathrm{OH}$ groups (type A). LklG (NRPS) also carries one KR domain that presumably reduces one 2-keto acid substrate to generate an $\mathrm{OH}$ group whose stereochemical configuration remains bioinformatically undefinable. In line with the predicted function of LklG-KR, the substrate of the LklG A domain is predicted to be a 2-keto acid and is assumed to be 2-keto-4-(methylthio) butyrate in looekeyolide biosynthesis (Figure 4a, Supporting Information 
p S18). Overall, bioinformatics analysis of all four isolated $l k l$ gene clusters indicated that they are highly likely to be responsible for the biosynthesis of looekeyolide A (1) (more details in Supporting Information pp S17, S18).

Natural Functions of Looekeyolides A (1) and B (2). Because $\mathrm{H}_{2} \mathrm{O}_{2}$ and other reactive oxygen species would be released as the $\mathrm{BBD}$ layer overgrows and destroys coral tissue, including associated endosymbiotic dinoflagellates (Symbiodinium spp.) that appear to be the source of $\mathrm{H}_{2} \mathrm{O}_{2},{ }^{14}$ we examined the role that looekeyolide $\mathrm{A}$ might play in reducing $\mathrm{H}_{2} \mathrm{O}_{2}$ due to its redox-sensitive functionality. Because pure $\mathbf{1}$ is unstable under aerobic conditions, and we had noticed that it was stabilized in the presence of lyngbic acid, we had to test the mixture for insights into its bioactivity. Serial concentrations of a looekeyolide mixture (1, 2, and lyngbic acid, 1:1:1, estimated by NMR), 2 alone, and lyngbic acid alone were incubated with $10 \mu \mathrm{M} \mathrm{H}_{2} \mathrm{O}_{2}$ at $37{ }^{\circ} \mathrm{C}$ in buffer. After $24 \mathrm{~h}$ of treatment, the $\mathrm{H}_{2} \mathrm{O}_{2}$ level was measured using a fluorimetric $\mathrm{H}_{2} \mathrm{O}_{2}$ assay kit. The $\mathrm{H}_{2} \mathrm{O}_{2}$ concentration was reduced to nearly zero when incubating with a $1 \mathrm{mM}$ looekeyolide mixture, while largely unaffected with either $\mathbf{2}$ or lyngbic acid alone, suggesting the ability of $\mathbf{1}$ to consume $\mathrm{H}_{2} \mathrm{O}_{2}$ (Figure 5a). High-performance liquid chromatography (HPLC) of the looekeyolide mixture after incubating with or without $\mathrm{H}_{2} \mathrm{O}_{2}$ for $24 \mathrm{~h}$ was used to quantify changes in the levels of $\mathbf{1}$ and 2 (Figure $5 b$ ). After incubating with $1 \mathrm{mM} \mathrm{H}_{2} \mathrm{O}_{2}$, the peak area of 1 significantly decreased to only $26 \%$ of the controls, while the peak area of $\mathbf{2}$ increased to $122 \%$ of controls, indicating the conversion of 1 to 2 through reaction with $\mathrm{H}_{2} \mathrm{O}_{2}$ (Figure $5 \mathrm{~b}, \mathrm{c}$ ).

We also assessed the stable compound looekeyolide B (2) in a range of ecologically relevant bioassays. To determine how looekeyolides might affect coral-associated microbiota, we looked for changes in the growth and biofilm formation of several coral-associated bacterial isolates, but did not find any effects of $\mathbf{2}$ at the concentrations tested (Supporting Information pp S16, S17, S19). We tested whether 2 might function as a siderophore, given its hydroxylated and highly substituted cyclized structure and the high iron demands of marine cyanobacteria for iron-rich enzymes required for both photosynthesis and nitrogen fixation, but electron paramagnetic resonance spectroscopy demonstrated that $\mathbf{2}$ does not bind $\mathrm{Fe}(\mathrm{III})$ (Supporting Information pp S16, S18). Looekeyolide B alone and a sample of looekeyolide A mixed with lyngbic acid ( 2:1 based on ${ }^{1} \mathrm{H}$ NMR) were embedded at natural concentrations in Phytagel strips in separate experiments, applied to surfaces of the coral Montastraea cavernosa along with control strips for $48 \mathrm{~h}$, and assessed for toxicity or inhibitory effects on photosynthetic performance using pulse amplitude modulated (PAM) fluorometry, following previously described methods. ${ }^{15}$ No adverse effects were observed on any corals tested (Supporting Information, pp S16, S17, S19).

Black band disease is a serious threat to coral reefs and causes mortality in dozens of coral species worldwide. ${ }^{1-5}$ Overgrowth by BBD leading to coral mortality may in part be mediated through secondary metabolites biosynthesized by the filamentous cyanobacterium $R$. reptotaenium, including the dominant natural product looekeyolide A (1). Looekeyolide A, a novel 20-membered macrocyclic polyketide/peptide hybrid, was detected in collections of more than a dozen BBD microbial consortia from the Caribbean and the Pacific and is unusual compared to other cyanobacterial secondary metabolites in containing a rare D-leucine, $2(S)$-hydroxymethionine, and a $\mathrm{C}_{16}$-polyketide chain. Secondary metabolites may be key to understanding interactions in the BBD microbial community, such as previously demonstrated for the role of lyngbic acid in inhibiting QS in Vibrio species. ${ }^{8}$ In addition to lyngbic acid, $R$. reptotaenium produces 1 as part of in situ BBD and in a laboratory culture. Other secondary metabolites of cyanobacteria, the microcystins, have been previously reported in $\mathrm{BBD} ;{ }^{16,17}$ however, we did not detect microcystins in any of our extracts of field-collected BBD or cultured Roseofilum, nor did we detect genes for the microcystins in metagenomic data previously reported. ${ }^{11}$ Additional antibiotic, terpene, NRPS, and PKS biosynthetic gene clusters were found in metagenome-assembled genomes from BBD consortia, ${ }^{11}$ suggesting other secondary metabolites remain to be discovered in BBD.

Looekeyolide A (1) autoxidizes to looekeyolide B (2), making it particularly challenging to assess the natural functions of $\mathbf{1}$. Thus, we could test $\mathbf{2}$ directly in various assays, but not the parent compound $\mathbf{1}$ by itself. Looekeyolide B did not show any toxicity, nor did it display antibacterial properties or function as a siderophore. Our data show that 1 may play a role in reducing $\mathrm{H}_{2} \mathrm{O}_{2}$ and other reactive oxygen species that could occur in the $\mathrm{BBD}$ layer as it overgrows and destroys coral tissue. $\mathrm{H}_{2} \mathrm{O}_{2}$ can transform into other labile reactive oxygen species and influence larger-scale ecological processes, such as coral bleaching. ${ }^{18,19}$ Various corals release $\mathrm{H}_{2} \mathrm{O}_{2}$ and antioxidants to their external environment, which can influence the $\mathrm{H}_{2} \mathrm{O}_{2}$ dynamics of reefs. ${ }^{20,21}$ Over $20 \mu \mathrm{mol}$ $\mathrm{L}^{-1} \mathrm{H}_{2} \mathrm{O}_{2}$ has been detected in the immediate coral diffusive boundary layer. ${ }^{14,21} \mathrm{H}_{2} \mathrm{O}_{2}$ release may aid corals in removing some of the internal $\mathrm{H}_{2} \mathrm{O}_{2}$ produced by their endosymbiotic algae and possibly have a defensive function. Looekeyolide $\mathrm{A}$ may allow Roseofilum to cope with this coral-produced source of $\mathrm{H}_{2} \mathrm{O}_{2}$, as it migrates across the coral colony.

It is also possible that the looekeyolides function as feeding deterrents that protect Roseofilum from consumption by grazers, similarly to other natural products from benthic marine cyanobacteria. ${ }^{22-24}$ Given the limited amounts of these unique natural products that can be obtained through collection or culture, having a synthetic route to looekeyolides will facilitate the testing of their role in chemical defense and the determination of other biological functions for the looekeyolides.

\section{EXPERIMENTAL SECTION}

General Experimental Procedures. The melting point measured using a Gallenkamp melting point apparatus is uncorrected. The optical rotations were recorded on a Jasco P2000 polarimeter. UV spectrophotometric data were acquired on a Shimadzu PharmaSpec UV-visible spectrophotometer. IR spectroscopic data were obtained on a Thermo Scientific iS5 FT-IR spectrometer. NMR data were collected on a JEOL ECA-600 spectrometer operating at $600.17 \mathrm{MHz}$ for ${ }^{1} \mathrm{H}$ and $150.9 \mathrm{MHz}$ for ${ }^{13} \mathrm{C}$. ${ }^{1} \mathrm{H}$ NMR chemical shifts (referenced to residual $\mathrm{CHD}_{2} \mathrm{CN}$ observed at $\delta_{\mathrm{H}} 1.93$ and residual $\mathrm{CHD}_{2} \mathrm{OD}$ at $\left.\delta_{\mathrm{H}} 3.30\right)$ were assigned using a combination of data from $2 \mathrm{D}$ DQF COSY and multiplicity-edited HSQC experiments. The edited-HSQC experiment was optimized for $J_{\mathrm{CH}}=140 \mathrm{~Hz}$, and the $\mathrm{HMBC}$ experiment was optimized for ${ }^{2 / 3} \mathrm{~J}_{\mathrm{CH}}=8 \mathrm{~Hz} \cdot{ }^{13} \mathrm{C}$ NMR chemical shifts (referenced to $\mathrm{CD}_{3} \mathrm{CN}$ observed at $\delta_{\mathrm{C}} 118.2$ and $\mathrm{CD}_{3} \mathrm{OD}$ at $\delta_{\mathrm{C}} 49.0$ ) were assigned on the basis of multiplicity-edited HSQC experiments. The LCMS data were obtained on an LC electrospray ionization MS system with an LTQ Advantage Max spectrometer (Thermo Finnigan). The HRMS data were obtained using an Agilent 6210 LC-TOF mass spectrometer equipped with an APCI/ESI multimode ion source detector at the Mass Spectrometer Facility at the University of California, Riverside, California. Silica gel 60 (EMD Chemicals, Inc., 230-400 mesh) and Varian BondElut octadecyl 
$\left(C_{18}\right)$ were used for column chromatography. All solvents used were of HPLC grade (Fisher Scientific).

Study Species. Samples of the BBD layer were collected in situ by aspiration with sterile, needleless syringes as previously described from the Florida Keys (Figure 1c), Belize, Honduras, and Guam. ${ }^{8}$ A BBD layer of an infected Montastraea cavernosa coral was collected at Looe Key Reef, Florida, on April 23, 2014, and used to isolate a unicyanobacterial enrichment culture of Roseofilum reptotaenium. This Roseofilum strain, isolated in unicyanobacterial, but not axenic culture as previously described, ${ }^{11}$ was grown in a medium containing 4 parts artificial seawater made from $36 \mathrm{~g} / \mathrm{L}$ Red Sea Coral Pro Salts or natural seawater and 1 part Cyanobacterial BG-11 media (ATCC medium 616), at $\mathrm{pH} 7$, room temperature, with $12 \mathrm{~h}$ of light and dark per day. Cyanobacterial cultures were confirmed as unicyanobacterial by amplifying extracted community DNA with cyanobacterial-specific $16 S$ rRNA primers ${ }^{25}$ and directly sequencing the cleaned PCR product by Sanger sequencing at the DNA Lab of Arizona State University (GenBank Accession No. KP689103). Full metagenomic and microbiome data on the samples we examined chemically have already been published. ${ }^{11}$

Biological Material Collection, Extraction, and Compound Isolation. For the chemical identification of major compounds present in situ within BBD consortia, samples were collected by aspiration of the entire BBD layer (mat) into $50-60 \mathrm{~mL}$ needleless syringes. Once aspirated, mats self-aggregated rapidly, and excessive seawater was removed. Within $1 \mathrm{~h}$ of collection, samples were frozen at $-20{ }^{\circ} \mathrm{C}$ and maintained frozen until the extraction as detailed below. Freeze-dried BBD mats were extracted with organic solvents (1:1 EtOAc-MeOH). Lipophilic extracts from all collected samples were analyzed by LRESI-LC-MS to screen for their production of secondary metabolites. Each sample $(10 \mu \mathrm{L})$ was injected and separated on a reversed-phase HPLC column (Grace; C18; $5 \mu \mathrm{m}, 2.1$ $\times 100 \mathrm{~mm}$ ) with step gradient elution of $0.1 \%$ formic acid in $\mathrm{H}_{2} \mathrm{O}$ (eluent A) and $100 \% \mathrm{CH}_{3} \mathrm{CN}$ (eluent $\mathrm{B}$ ). The gradient program was as follows: $0-22 \mathrm{~min}, \mathrm{~B}, 20-100 \%$; flow rate, $700 \mu \mathrm{L} \cdot \mathrm{min}^{-1}$. The column temperature was kept at $30^{\circ} \mathrm{C}$. The MS spectra and retention time of each peak were recorded using the positive and negative ion detection modes.

The lipophilic extract was subsequently partitioned between EtOAc and $\mathrm{H}_{2} \mathrm{O}$. The EtOAc-soluble portion was fractionated by reversedphase $\mathrm{C} 18$ chromatography followed by reversed-phase C18 HPLC to give the new compounds looekeyolides $\mathrm{A}$ and $\mathrm{B}$, which had been observed as major metabolites in the EtOAc partitions by LCMS and proton NMR analyses. The relative yields of the two looekeyolides isolated from different batches were highly dependent on the conditions used for extraction and separation methods.

The black band mat of Orbicella annularis and Pseudodiploria strigosa were collected in Belize (Smithsonian Carrie Bow Cay Field Station) on March 1, 2013. These collections were freeze-dried to give a dry weight of 7.9 and $3.04 \mathrm{~g}$ from Orbicella spp. and P. strigosa, respectively. Each collection was extracted successively with $50 \mathrm{~mL}$ of EtOAc, $\mathrm{MeOH}$, and $\mathrm{MeOH}-\mathrm{H}_{2} \mathrm{O}(1: 1)$. The three extracts were combined and concentrated by rotary evaporation at $45{ }^{\circ} \mathrm{C}$ under reduced pressure. Each concentrated extract was separately partitioned between EtOAc and $\mathrm{H}_{2} \mathrm{O}$. The $\mathrm{H}_{2} \mathrm{O}$-soluble fractions were repartitioned between $n-\mathrm{BuOH}$ and $\mathrm{H}_{2} \mathrm{O}$. Concentration of these extracts furnished $0.063 \mathrm{~g}$ of EtOAc-soluble fraction from the Orbicella collection and $0.041 \mathrm{~g}$ of EtOAc-soluble fraction from the Pseudodiploria collection. The ${ }^{1} \mathrm{H}$ NMR spectra of these EtOAcsoluble fractions from the two coral species indicated the presence of the same set of major compounds, and therefore, these two extracts were combined for further studies. The combined EtOAc extract $(0.104 \mathrm{~g})$ was chromatographed on a column of $\mathrm{C}_{18}(10 \mathrm{~g})$ using a $\mathrm{MeOH}-\mathrm{H}_{2} \mathrm{O}$ step gradient system to give 11 subfractions. The subfraction $7(0.004 \mathrm{~g})$, eluted with $\mathrm{MeOH}-\mathrm{H}_{2} \mathrm{O}$ (7:3), was further separated by reversed-phase HPLC (semipreparative, $5 \mu \mathrm{m}, \mathrm{RP}_{-} \mathrm{C}_{18}$ ) using $\mathrm{MeOH}-\mathrm{H}_{2} \mathrm{O}$ (7:3) to give $2.6 \mathrm{mg}$ of a new compound, looekeyolide B (2). Similarly, the HPLC of subfraction 8 (0.003 g), eluted with $\mathrm{MeOH}-\mathrm{H}_{2} \mathrm{O}$ (8:2), furnished an additional $1.4 \mathrm{mg}$ of 2 to give a total yield of $4.0 \mathrm{mg}$ (yield, $0.035 \%$ dry wt) from this collection.

A second batch of the black band mat from Orbicella spp. and $P$. strigosa was collected in Belize (Carrie Bow Cay Field Station) on July 13-17, 2013. The freeze-dried material of $9.43 \mathrm{~g}$ was extracted with $\mathrm{MeOH}$ saturated with helium gas. All subsequent partitioning and chromatography methods were performed using helium gas saturated solvents. This $\mathrm{MeOH}$ extract $(1.82 \mathrm{~g})$ was partitioned between EtOAc and $\mathrm{H}_{2} \mathrm{O}$ to give the EtOAc-soluble fraction $(0.237 \mathrm{~g})$ and $\mathrm{H}_{2} \mathrm{O}$ soluble fraction. The EtOAc extract was chromatographed on a column of $\mathrm{C}_{18}(16 \mathrm{~g})$ using a $\mathrm{MeOH}-\mathrm{H}_{2} \mathrm{O}$ step gradient system to give six subfractions. Subfraction $3(0.006 \mathrm{~g})$, eluted with $\mathrm{MeOH}-$ $\mathrm{H}_{2} \mathrm{O}$ (7:3), was further separated by reversed-phase HPLC using the same conditions to give $2.6 \mathrm{mg}$ of looekeyolide B (2). Low-resolution ESI mass spectral analysis by direct injection method of 2 gave a mass peak at $\mathrm{m} / z$ of 702 for $(\mathrm{M}+\mathrm{Na})^{+}$. The subfraction $4(0.023 \mathrm{~g})$, eluted with $\mathrm{MeOH}-\mathrm{H}_{2} \mathrm{O}$ (8:2), was analyzed by ${ }^{1} \mathrm{H}$ NMR and LRESIMS by the direct injection method. The ${ }^{1} \mathrm{H}$ NMR spectrum of this subfraction 4 indicated the presence of a related looekeyolide A (1) together with an unsaturated fatty acid as an impurity. LRESIMS of this subfraction gave a mass peak at $m / z$ of 686 for $(\mathrm{M}+\mathrm{Na})^{+}$, indicating a difference of 16 mass units attributed to one less oxygen atom in the related looekeyolide A (1). A portion of this fraction (12 $\mathrm{mg}$ ) on purification by HPLC using the same conditions yielded 2 (3 $\mathrm{mg}$ ), instead of the expected related looekeyolide (1). The ${ }^{1} \mathrm{H}$ NMR and LRMS data suggested that $\mathbf{1}$ is unstable under these conditions and easily oxidized to 2 during the HPLC separation. Another portion of subfraction $4(0.004 \mathrm{~g})$ on purification by HPLC using heliumdegassed solvents with minimum exposure to air furnished the naturally occurring compound looekeyolide A (1, 0.0009 g), its oxidized product looekeyolide B $(2,0.001 \mathrm{~g})$, and a mixture of fatty acids $(0.002 \mathrm{~g})$.

Three small batches of the black band mat were also collected from $M$. cavernosa in the Florida Keys. The first batch was collected from Wonderland Reef in June 2013. Two more batches were collected from Looe Key in June and November 2013. These batches were separately subjected to purification using the methods described above. The Wonderland Reef batch of dry weight of $0.034 \mathrm{~g}$ gave 0.1 mg of looekeyolide B (2). Similarly, the Looe Key batches of dry weights of 1.055 and $1.585 \mathrm{~g}$ furnished $0.3 \mathrm{mg}$ and $0.4 \mathrm{mg}$ of 2 , respectively.

On November 20, 2013, another batch of the black band mat was collected from Looe Key for studies. This batch of dry weight $1.109 \mathrm{~g}$ furnished $0.3 \mathrm{mg}$ of looekeyolide B (2). Similarly, another batch was collected from Looe Key in April 2014. This batch of dry weight 3.672 $\mathrm{g}$ yielded $4.7 \mathrm{mg}$ of looekeyolide A, $2.1 \mathrm{mg}$ of looekeyolide B, and 5.2 $\mathrm{mg}$ of fatty acid. HRMS data [HRESI/APCIMS $m / z$ 257.2127 [M + $\mathrm{H}]^{+}$(calcd for $\left.\left.\mathrm{C}_{15} \mathrm{H}_{29} \mathrm{O}_{3}, 257.2117\right)\right]$ identified this fatty acid as lyngbic acid. The structure of lyngbic acid was confirmed by comparing the ${ }^{1} \mathrm{H}$ NMR and ${ }^{13} \mathrm{C}$ NMR data of an authentic sample of lyngbic acid. This lyngbic acid gave a specific rotation value of $[\alpha]_{D}^{25}-12.0\left(c 0.06, \mathrm{CHCl}_{3}\right)$, similar to the specific rotation value of lyngbic acid reported from other marine cyanobacteria. ${ }^{9}$ Subsequently, we noticed that looekeyolide $\mathrm{A}$ is more stable in the presence of lyngbic acid.

Looekeyolide A (1): white solid; $[\alpha]_{\mathrm{D}}^{25}+24.0$ (c 0.06, MeOH); UV $(\mathrm{MeOH}) \lambda_{\max }(\log \varepsilon) 220$ (3.28); IR (solid smear) $\nu_{\max } 3400,2956$, 2928, 1737, 1682, 1563,1454,1151,1095, 1042, 963, $931 \mathrm{~cm}^{-1} ;{ }^{1} \mathrm{H}$ NMR $\left(600 \mathrm{MHz}, \mathrm{CD}_{3} \mathrm{OD}\right) \delta 4.96(1 \mathrm{H}, \mathrm{dd}, J=9.6,6.1 \mathrm{~Hz}, \mathrm{H}-13)$, $4.93(1 \mathrm{H}, \mathrm{dd}, J=8.9,4.0 \mathrm{~Hz}, \mathrm{H}-29), 4.72(1 \mathrm{H}, \mathrm{dd}, J=11.0,1.8 \mathrm{~Hz}$, H-11), $4.55(1 \mathrm{H}, \mathrm{dd}, 10.8,4.2 \mathrm{~Hz}, \mathrm{H}-23), 4.38(1 \mathrm{H}, \mathrm{dd}, J=10.3,4.1$ Hz, H-3), 3.63 (1H, ddd, $J=11.0,11.0,2.0 \mathrm{~Hz}, \mathrm{H}-5), 3.45(1 \mathrm{H}, \mathrm{dd}, J$ $=12.0,4.8 \mathrm{~Hz}, \mathrm{H}-7), 3.39\left(3 \mathrm{H}, \mathrm{s}, \mathrm{OCH}_{3}-19\right), 3.33\left(3 \mathrm{H}, \mathrm{s}, \mathrm{OCH}_{3}-17\right)$, $2.61(2 \mathrm{H}, \mathrm{m}, \mathrm{H}-31), 2.59(1 \mathrm{H}, \mathrm{d}, J=17.8, \mathrm{~Hz}, \mathrm{H}-2 \mathrm{a}), 2.36(1 \mathrm{H}, \mathrm{dd}, J$ = 17.8, $10.9 \mathrm{~Hz}, \mathrm{H}-2 \mathrm{~b}), 2.22(1 \mathrm{H}, \mathrm{m}, \mathrm{H}-4), 2.16(1 \mathrm{H}, \mathrm{m}, \mathrm{H}-14 \mathrm{a}), 2.09$ (1H, m, H-6a), $2.08\left(3 \mathrm{H}, \mathrm{s}, \mathrm{CH}_{3}-32\right), 2.07(\mathrm{H}, \mathrm{m}, \mathrm{H}-30 \mathrm{a}), 1.94(\mathrm{H}$, m, H-30b), 1.89 (1H, dd, $J=14.4,11.6 \mathrm{~Hz}, \mathrm{H}-10 \mathrm{a}), 1.75$ (1H, ddd, $J$ $=15.1,10.9,4.1 \mathrm{~Hz}, \mathrm{H}-24 \mathrm{a}), 1.68(1 \mathrm{H}, \mathrm{dd}, J=14.4,2.4 \mathrm{~Hz}, \mathrm{H}-10 \mathrm{~b})$, $1.65(1 \mathrm{H}, \mathrm{m}, \mathrm{H}-24 \mathrm{~b}), 1.64(1 \mathrm{H}, \mathrm{m}, \mathrm{H}-25), 1.53(1 \mathrm{H}, \mathrm{m}, \mathrm{H}-14 \mathrm{~b})$, $1.49(1 \mathrm{H}, \mathrm{q}, J=7.5 \mathrm{~Hz}, \mathrm{H}-12), 1.42(1 \mathrm{H}, \mathrm{ddd}, J=11.7,11.7,11.7 \mathrm{~Hz}$, 
H-6b), 1.33 (1H, m, H-15a), 1.25 (3H, s, $\left.\mathrm{CH}_{3}-20\right), 1.24$ (1H, m, H$15 \mathrm{~b}), 0.96\left(3 \mathrm{H}, \mathrm{d}, J=6.2 \mathrm{~Hz}, \mathrm{CH}_{3}-27\right), 0.95\left(3 \mathrm{H}, \mathrm{d}, J=7.5 \mathrm{~Hz}, \mathrm{CH}_{3}\right.$ 21), $0.91\left(3 \mathrm{H}, \mathrm{t}, J=6.3 \mathrm{~Hz}, \mathrm{CH}_{3}-16\right), 0.85\left(3 \mathrm{H}, \mathrm{d}, J=6.1 \mathrm{~Hz}, \mathrm{CH}_{3}\right.$ 26), $0.84\left(3 \mathrm{H}, \mathrm{d}, J=6.8 \mathrm{~Hz}, \mathrm{CH}_{3}-18\right) ;{ }^{13} \mathrm{C}$ NMR $\left(\mathrm{CD}_{3} \mathrm{OD}\right) \delta 174.6$ (C, C-28), 173.6 (C, C-1), 172.5 (C, C-22), 102.1 (C, C-9), 81.2 (CH, C-13), 80.1 (CH, C-7), 77.7 (CH, C-3), 74.7 (C, C-8), 74.2 (CH, C-29), 70.8 (CH, C-5), $66.7(\mathrm{CH}, \mathrm{C}-11), 57.7\left(\mathrm{OCH}_{3}, \mathrm{C}-19\right)$, $57.4\left(\mathrm{OCH}_{3}, \mathrm{C}-17\right), 50.5(\mathrm{CH}, \mathrm{C}-23), 42.8(\mathrm{CH}, \mathrm{C}-12), 38.8\left(\mathrm{CH}_{2}\right.$, C-24), 38.7 (CH, C-4), $37.3\left(\mathrm{CH}_{2}, \mathrm{C}-10\right), 35.4\left(\mathrm{CH}_{2}, \mathrm{C}-14\right), 33.6$ $\left(\mathrm{CH}_{2}, \mathrm{C}-2\right), 32.5\left(\mathrm{CH}_{2}, \mathrm{C}-30\right), 31.4\left(\mathrm{CH}_{2}, \mathrm{C}-6\right), 30.5\left(\mathrm{CH}_{2}, \mathrm{C}-31\right)$, $26.0(\mathrm{CH}, \mathrm{C}-25), 23.6\left(\mathrm{CH}_{3}, \mathrm{C}-27\right), 21.1\left(\mathrm{CH}_{3}, \mathrm{C}-26\right), 20.3\left(\mathrm{CH}_{2}\right.$, C-15), $19.6\left(\mathrm{CH}_{3}, \mathrm{C}-20\right), 15.2\left(\mathrm{CH}_{3}, \mathrm{C}-32\right), 14.3\left(\mathrm{CH}_{3}, \mathrm{C}-16\right), 12.0$ $\left(\mathrm{CH}_{3}, \mathrm{C}-21\right), 9.7\left(\mathrm{CH}_{3}, \mathrm{C}-18\right)$; HRESI/APCIMS $m / z 686.3528[\mathrm{M}+$ $\mathrm{Na}]^{+}$(calcd for $\mathrm{C}_{32} \mathrm{H}_{57} \mathrm{NO}_{11} \mathrm{SNa}, 686.3545$ ).

Looekeyolide $B(2)$ : white, amorphous powder; $[\alpha]_{D}^{25}+36.1(c$ $0.22, \mathrm{MeOH}) ; \mathrm{UV}(\mathrm{MeOH}) \lambda_{\max }(\log \varepsilon) 220$ (3.44); IR (solid smear) $\nu_{\max } 3400,2957,2934,1736,1679,1555,1151,1095,1052,1032$, $1010,752 \mathrm{~cm}^{-1}$; ${ }^{1} \mathrm{H}$ NMR, ${ }^{13} \mathrm{C}$ NMR, DQF COSY, HMBC, and NOESY data, see Table 1; HRESI/APCIMS $m / z$ 702.3528 [M + $\mathrm{Na}]^{+}$(calcd for $\mathrm{C}_{32} \mathrm{H}_{57} \mathrm{NO}_{12} \mathrm{SNa}, 702.3493$ ).

Desulfurization. Looekeyolide B $(2,4.5 \mathrm{mg})$ was dissolved in $\mathrm{EtOH}(0.5 \mathrm{~mL})$ and treated with an excess of fresh Raney-Ni (2400) as a slurry in $\mathrm{H}_{2} \mathrm{O}(0.1 \mathrm{~mL})$ and refluxed for $0.5 \mathrm{~h}$. The product was filtered and concentrated to give a white solid. This solid was further purified by reversed-phase HPLC (semipreparative, $5 \mu \mathrm{m}, \mathrm{RP}_{-} \mathrm{C}_{18}$ ) using $\mathrm{MeOH}-\mathrm{H}_{2} \mathrm{O}(8.5-1.5)$ to give $3.7 \mathrm{mg}$ of the desulfurized compound des-thiomethylooekeyolide A (3). This material on crystallization in a mixture of benzene and hexanes (1:95) yielded colorless crystals of des-thiomethylooekeyolide A (3). A selected crystal from this batch was used in X-ray crystallography studies.

des-Thiomethylooekeyolide A (3): colorless crystals; mp 196-197 ${ }^{\circ} \mathrm{C} ;[\alpha]^{25}+29.3(c 0.05, \mathrm{MeOH}) ; \mathrm{UV}(\mathrm{MeOH}) \lambda_{\max }(\log \varepsilon) 220$ (3.27); IR (solid smear) $\nu_{\max } 3303,2929,2934,1737,1667,1644$, $1551,1458,1277,1152,1095,1012,969,935,752 \mathrm{~cm}^{-1} ;{ }^{1} \mathrm{H}$ NMR $\left(600 \mathrm{MHz}, \mathrm{CD}_{3} \mathrm{OD}\right) \delta 4.96(1 \mathrm{H}, \mathrm{dd}, J=9.6,6.1 \mathrm{~Hz}, \mathrm{H}-13), 4.72$ $(1 \mathrm{H}, \mathrm{dd}, J=11.0,1.8 \mathrm{~Hz}, \mathrm{H}-11), 4.71(1 \mathrm{H}, \mathrm{dd}, J=8.4,4.8 \mathrm{~Hz}, \mathrm{H}-29)$, $4.55(1 \mathrm{H}, \mathrm{dd}, 10.8,4.2 \mathrm{~Hz}, \mathrm{H}-23), 4.38(1 \mathrm{H}, \mathrm{dd}, J=10.9,4.8 \mathrm{~Hz}, \mathrm{H}-$ 3), $3.62(1 \mathrm{H}, \mathrm{ddd}, J=10.2,10.2,3.0 \mathrm{~Hz}, \mathrm{H}-5), 3.44(1 \mathrm{H}, \mathrm{dd}, J=12.0$, $4.8 \mathrm{~Hz}, \mathrm{H}-7), 3.39$ ( $\left.3 \mathrm{H}, \mathrm{s}, \mathrm{OCH}_{3}-19\right), 3.33\left(3 \mathrm{H}, \mathrm{s}, \mathrm{OCH}_{3}-17\right), 2.56$ $(1 \mathrm{H}, \mathrm{d}, J=17.8,10.9 \mathrm{~Hz}, \mathrm{H}-2 \mathrm{a}), 2.36(1 \mathrm{H}, \mathrm{dd}, J=17.8,10.9 \mathrm{~Hz}, \mathrm{H}-$ 2b), $2.22(1 \mathrm{H}, \mathrm{m}, \mathrm{H}-4), 2.16$ (1H, m, H-14a), 2.09 (1H, ddd, $J=11.7$, 4.8, $2.7 \mathrm{~Hz}, \mathrm{H}-6 \mathrm{a}), 1.89(1 \mathrm{H}, \mathrm{dd}, J=14.4,11.6 \mathrm{~Hz}, \mathrm{H}-10 \mathrm{a}), 1.80(1 \mathrm{H}$, m, Ha-30), $1.76(1 \mathrm{H}, \mathrm{m}, \mathrm{Hb}-30), 1.74(1 \mathrm{H}, \mathrm{m}, \mathrm{H}-24 \mathrm{a}), 1.68(1 \mathrm{H}, \mathrm{dd}$, $J=14.4,2.4 \mathrm{~Hz}, \mathrm{H}-10 \mathrm{~b}), 1.64(1 \mathrm{H}, \mathrm{m}, \mathrm{H}-25), 1.62(1 \mathrm{H}, \mathrm{m}, \mathrm{H}-24 \mathrm{~b})$, $1.53(1 \mathrm{H}, \mathrm{m}, \mathrm{H}-14 \mathrm{~b}), 1.49$ (1H, q, $J=7.5 \mathrm{~Hz}, \mathrm{H}-12), 1.42(1 \mathrm{H}, \mathrm{ddd}, J$ $=11.7,11.7,11.7 \mathrm{~Hz}, \mathrm{H}-6 \mathrm{~b}), 1.33(1 \mathrm{H}, \mathrm{m}, \mathrm{H}-15 \mathrm{a}), 1.25\left(3 \mathrm{H}, \mathrm{s}, \mathrm{CH}_{3}-\right.$ 20), $1.24(1 \mathrm{H}, \mathrm{m}, \mathrm{H}-15 \mathrm{~b}), 1.02\left(3 \mathrm{H}, \mathrm{t}, J=7.5 \mathrm{~Hz}, \mathrm{CH}_{3}-31\right), 0.96$ $\left(3 \mathrm{H}, \mathrm{d}, J=6.2 \mathrm{~Hz}, \mathrm{CH}_{3}-27\right), 0.95\left(3 \mathrm{H}, \mathrm{d}, J=7.5 \mathrm{~Hz}, \mathrm{CH}_{3}-21\right), 0.91$ $\left(3 \mathrm{H}, \mathrm{t}, J=6.3 \mathrm{~Hz}, \mathrm{CH}_{3}-16\right), 0.85\left(3 \mathrm{H}, \mathrm{d}, J=6.1 \mathrm{~Hz}, \mathrm{CH}_{3}-26\right), 0.84$ $\left(3 \mathrm{H}, \mathrm{d}, J=6.8 \mathrm{~Hz}, \mathrm{CH}_{3}-18\right) ;{ }^{13} \mathrm{C}$ NMR $\left(\mathrm{CD}_{3} \mathrm{OD}\right) \delta 174.9(\mathrm{C}, \mathrm{C}-28)$, 173.6 (C, C-1), 172.5 (C, C-22), 102.1 (C, C-9), 81.2 (CH, C-13), $80.1(\mathrm{CH}, \mathrm{C}-7), 77.7$ (CH, C-3), 76.8 (CH, C-29), 74.7 (C, C-8), $70.8(\mathrm{CH}, \mathrm{C}-5), 66.7(\mathrm{CH}, \mathrm{C}-11), 57.7\left(\mathrm{OCH}_{3}, \mathrm{C}-19\right), 57.4\left(\mathrm{OCH}_{3}\right.$, C-17), 50.5 (CH, C-23), 42.7 (CH, C-12), $38.8\left(\mathrm{CH}_{2}, \mathrm{C}-24\right), 38.7$ (CH, C-4), $37.3\left(\mathrm{CH}_{2}, \mathrm{C}-10\right), 35.4\left(\mathrm{CH}_{2}, \mathrm{C}-14\right), 33.6\left(\mathrm{CH}_{2}, \mathrm{C}-2\right)$, $31.4\left(\mathrm{CH}_{2}, \mathrm{C}-6\right), 26.1\left(\mathrm{CH}_{2}, \mathrm{C}-30\right), 25.8(\mathrm{CH}, \mathrm{C}-25), 23.6\left(\mathrm{CH}_{3}, \mathrm{C}-\right.$ 27), $21.1\left(\mathrm{CH}_{3}, \mathrm{C}-26\right), 20.3\left(\mathrm{CH}_{2}, \mathrm{C}-15\right), 19.7\left(\mathrm{CH}_{3}, \mathrm{C}-20\right), 14.3$ $\left(\mathrm{CH}_{3}, \mathrm{C}-16\right), 12.0\left(\mathrm{CH}_{3}, \mathrm{C}-21\right), 10.1\left(\mathrm{CH}_{3}, \mathrm{C}-31\right), 9.7\left(\mathrm{CH}_{3}, \mathrm{C}-18\right)$; HRESI/APCIMS $\mathrm{m} / \mathrm{z} 640.3685[\mathrm{M}+\mathrm{Na}]^{+}$(calcd for $\mathrm{C}_{31} \mathrm{H}_{55} \mathrm{NO}_{11} \mathrm{Na}$, 640.3667).

Acid Hydrolysis and Chiral HPLC Analysis. des-Thiomethylooekeyolide $\mathrm{A}(3,0.2 \mathrm{mg})$ was suspended in $6 \mathrm{~N} \mathrm{HCl}(0.3 \mathrm{~mL})$ and heated at $115{ }^{\circ} \mathrm{C}$ for $18 \mathrm{~h}$ in a sealed tube. The hydrolysate was concentrated to dryness. The residue was reconstituted in $0.2 \mathrm{~mL}$ of $\mathrm{H}_{2} \mathrm{O}$ and analyzed by chiral HPLC, comparing the retention times with those of authentic standards [Phenomenex Chirex (D) Penicillamine, $4.6 \times 250 \mathrm{~mm}, 5 \mu \mathrm{m}$ ]; detection at $254 \mathrm{~nm}$. Using the solvent mixture of $2.0 \mathrm{mM} \mathrm{CuSO}{ }_{4}-\mathrm{MeCN}$ (90:10), with a flow rate of $1.0 \mathrm{~mL} / \mathrm{min}$, the retention times $\left(t_{\mathrm{R}} \mathrm{min}\right)$ for authentic standards were 22.2 for L-Leu and 25.4 for D-Leu. The $t_{\mathrm{R}} \min$ of the amino acid in the hydrolysate under the same HPLC conditions was 25.4, indicating the presence of D-Leu in the hydrolysate. The stereochemistry of the $\alpha$-hydroxy acid was determined using a different chiral column for the HPLC analysis [CHIRALPAK MA (+) $(4.6 \times 50 \mathrm{~mm})$, Diacel Chemical industries, Ltd.; solvent, $2.0 \mathrm{mM}$ $\mathrm{CuSO}_{4}-\mathrm{MeCN}$ (95:5); flow rate, $1.0 \mathrm{~mL} / \mathrm{min}$; detection at $254 \mathrm{~nm}$ ]. The $t_{\mathrm{R}}$ min for authentic standards were 7.0 for $\mathrm{R}-\mathrm{Hba}$ and 10.0 for $S$ $\mathrm{Hba}$. The retention time of the $\alpha$-hydroxy acid in the hydrolysate under these conditions was 10.0, indicating the presence of $S$ - Hba in the hydrolysate.

Single-Crystal X-ray Structure Determination of desThiomethyllooekeyolide A (3). A selected colorless crystal of 3 was used in this study. X-ray intensity data were collected at $100 \mathrm{~K}$ on a Bruker DUO diffractometer using $\mathrm{Cu} \mathrm{K} \alpha$ radiation $(\lambda=1.54178$ $\AA$ ), from an ImuS power source, and an APEXII CCD area detector. Raw data frames were read by the program SAINT and integrated using $3 \mathrm{D}$ profiling algorithms. The resulting data were reduced to produce $h k l$ reflections and their intensities and estimated standard deviations. The data were corrected for Lorentz and polarization effects, and numerical absorption corrections were applied based on indexed and measured faces. The structure was solved and refined in SHELXTL2013, using full-matrix least-squares refinement. The non$\mathrm{H}$ atoms were refined with anisotropic thermal parameters, and all of the $\mathrm{H}$ atoms were calculated in idealized positions and refined riding on their parent atoms. The structure refined with this data confirms the absolute configuration to be correct as presented here based on the value of the Flack $x$ parameter of $0.02(16) . \mathrm{All}_{2} \mathrm{O}$ and hydroxy protons were obtained from a difference Fourier map and refined freely. All of those protons are involved in an extensive network of hydrogen bonding. In the final cycle of refinement, 6020 reflections (of which 5945 are observed with $I>2 \sigma(I)$ ) were used to refine 419 parameters, and the resulting $R_{1}, w R_{2}$, and $S$ (goodness of fit) were $3.22 \%, 8.91 \%$, and 1.076 , respectively. The refinement was carried out by minimizing the $w R_{2}$ function using $F^{2}$ rather than $F$ values. $R_{1}$ is calculated to provide a reference to the conventional $R$ value, but its function is not minimized.

Identifying the Biosynthetic Gene Cluster. DNA was extracted from the BBD layer or from the unicyanobacterial culture with a PowerSoil DNA isolation kit (MoBio) or Qiagen AllPrep DNA/RNA Micro kit, as previously described. ${ }^{11}$ Metagenomic libraries were constructed with a TruSeq DNA sample preparation kit (Illumina, San Diego, CA, USA) and sequenced at the University of Maryland Institute for Bioscience and Biotechnology Research on an Illumina HiSeq with a $100 \mathrm{bp}$ paired-end protocol. The unassembled, quality-filtered reads are publicly available through NCBI's Sequence Read Archive (SRA) under the BioProject ID PRJNA269585. Quality-filtering, metagenomic assembly, and the recovery of metagenome-assembled genomes were previously described. ${ }^{11}$ Biosynthetic gene clusters in the Roseofilum MAGs were identified with antiSMASH v. 3.0 to predict open reading frames (ORFs). ${ }^{26}$ The predicted ORFs were annotated by performing BLASTp against the NCBI database. Sequence motifs of KR, AT, and MT domains were determined after protein sequence alignment by ClustalW, and the corresponding figures were prepared with Jalview $2{ }^{27}$ The specificity codes of A domains were predicted with NRPSpredictor2. ${ }^{28}$

$\mathrm{H}_{2} \mathrm{O}_{2}$ Activity of Looekeyolide A (1) and Looekeyolide B (2). Serial concentrations of stock solutions of looekeyolide mixture (1:2:lyngbic acid 1:1:1, estimated by NMR), 2 alone, and lyngbic acid alone dissolved in DMSO (0.5 $\mu \mathrm{L}$ each) were incubated with $49.5 \mu \mathrm{L}$ of $10 \mu \mathrm{M} \mathrm{H}_{2} \mathrm{O}_{2}$ (prepared using the buffer in the assay kit) at $37^{\circ} \mathrm{C}$ in a 96-well plate. Equivalent amounts of DMSO were used as controls. After a $24 \mathrm{~h}$ treatment, the $\mathrm{H}_{2} \mathrm{O}_{2}$ level was measured using the fluorimetric $\mathrm{H}_{2} \mathrm{O}_{2}$ assay kit (Sigma-Aldrich) according to the manufacturer's instructions $(n=2)$. Briefly, the master mix was first prepared by mixing the red peroxidase substrate and the horseradish peroxidase with the assay buffer. Master mix $(50 \mu \mathrm{L})$ was added to each well, and the plate was incubated for $20 \mathrm{~min}$ at room temperature in the dark. The fluorescence intensity $\left(\lambda_{\mathrm{ex}}=540 / \lambda_{\mathrm{em}}\right.$ $=590 \mathrm{~nm}$ ) was then recorded on a SpectraMax M5 (Molecular 
Devices). The fold change in $\mathrm{H}_{2} \mathrm{O}_{2}$ level for each sample was calculated by first subtracting the background values for buffer + DMSO and then comparing the treatment to the DMSO control (value for treatment - average value for background)/(value for control - average value for background).

HPLC analysis was performed on a Shimadzu LC-20AB prominence liquid chromatography system with peak detection by a Shimadzu SPD-20A prominence UV/vis detector. Serial concentrations of $\mathrm{H}_{2} \mathrm{O}_{2}(10 \mu \mathrm{L})$ were incubated with $990 \mu \mathrm{L}$ of $10 \mu \mathrm{M} \mathrm{LK}$ mixture (prepared using the same buffer as the $\mathrm{H}_{2} \mathrm{O}_{2}$ assay) in $1.5 \mathrm{~mL}$ Eppendorf tubes at $37{ }^{\circ} \mathrm{C}$ (Thermomixer, mixed at $400 \mathrm{rpm}$ for 10 min). After a $24 \mathrm{~h}$ treatment, $300 \mu \mathrm{L}$ of EtOAc was added and subsequently spiked with nocodazole as the internal standard. The mixtures were vigorously vortexed for $10 \mathrm{~s}$ and centrifuged at $1500 \mathrm{~g}$ for $30 \mathrm{~s}$, and the EtOAc layer was transferred to a new tube. The extraction step was repeated one more time, and the collected EtOAc layers were combined and evaporated to dryness under nitrogen. Samples were reconstituted in $20 \mu \mathrm{L}$ of $\mathrm{MeOH}$ and injected into the HPLC system for analysis: column, Phenomenex Synergi $4 \mu$ Hydro$\mathrm{RP} 80 \AA 250 \times 4.68 \mathrm{~mm}, 4 \mu \mathrm{m}$; flow rate, $0.5 \mathrm{~mL} / \mathrm{min}$; UV detection at $220 \mathrm{~nm}$; linear gradient $\mathrm{MeCN}-\mathrm{H}_{2} \mathrm{O}(50-100 \% \mathrm{MeCN}$ in $40 \mathrm{~min}$, $100 \% \mathrm{MeCN}$ for $10 \mathrm{~min}$, and then $100-80 \% \mathrm{MeCN}$ in $10 \mathrm{~min}$ ). The retention times of nocodazole, LK-B, and LK-A were 10.6, 13.8, and $29.1 \mathrm{~min}$, respectively. The fold changes of the HPLC peak area of 1 and 2 were calculated by comparing the ratio of the normalized peak area in each $\mathrm{H}_{2} \mathrm{O}_{2}$-treated sample with the corresponding value in the DMSO control sample (peak area of looekeyolide in treatment/peak area of nocodazole in treatment)/(peak area of looekeyolide in control/peak area of nocodazole in control). Graphs and data analysis were performed using the Prism software and analyzed using ANOVA followed by Dunnett's test.

Ethics. All permits were in place for collection of these samples from the Florida Keys National Marine Sanctuary (FKNMS-2013023, FKNMS-2015-078-A1), the Belize Fisheries Department, and the Guam Department of Agriculture Division of Aquatic and Wildlife Resources.

Data Accessibility. All data are deposited in publicly accessible databases (NCBI, CCDC, IMG) as noted in the article. All NMR data and additional data are provided in the Supporting Information.

\section{ASSOCIATED CONTENT}

\section{S Supporting Information}

The Supporting Information is available free of charge on the ACS Publications website at DOI: 10.1021/acs.jnatprod.8b00804.

$$
\begin{aligned}
& \text { Additional information (PDF) } \\
& \text { X-ray crystallographic data (CIF) }
\end{aligned}
$$

\section{AUTHOR INFORMATION}

\section{Corresponding Author}

*E-mail: paul@si.edu.

\section{ORCID}

Yousong Ding: 0000-0001-8610-0659

Alexander Angerhofer: 0000-0002-8580-6024

Tao Ye: 0000-0002-2780-9761

Hendrik Luesch: 0000-0002-4091-7492

Valerie J. Paul: 0000-0002-4691-1569

Notes

The authors declare no competing financial interest.

\section{ACKNOWLEDGMENTS}

J.L.M. was supported by the L'Oréal USA for Women in Science Fellowship and M.T. by the George E. Burch Fellowship in Theoretic Medicine and Affiliated Theoretic Science from the Smithsonian Institution. This research was supported by NIH R01CA172310 (H.L., V.J.P.), NIH 1R35GM128742 (Y.D.), Shenzhen Peacock Plan KQTD2015071714043444 (T.Y.), and Mote Marine Laboratory Protect Our Reefs grants POR 2012-1, POR 2013-2 and POR 2014-10, POR 2015-1 (M.T., V.J.P.). We thank E. Bartels, C. Walters. L. Johnston, and C. Thacker for assistance with sample collection. We are grateful to Florida Atlantic University and its Harbor Branch Oceanographic Institute for access to their spectrometer facilities. K.A.A. wishes to acknowledge the National Science Foundation and the University of Florida for funding for the purchase of the Xray equipment. This is contribution \#1005 of the Smithsonian Caribbean Coral Reef Ecosystem and contribution \#1102 of the Smithsonian Marine Station.

\section{REFERENCES}

(1) Sato, Y.; Civiello, M.; Bell, S. C.; Willis, B. L.; Bourne, D. G. Environ. Microbiol. 2016, 18, 752-765.

(2) Kuta, K. G.; Richardson, L. L. Coral Reefs 2002, 21, 393-398.

(3) Frias-Lopez, J.; Zerkle, A. L.; Bonheyo, G. T.; Fouke, B. W. Appl. Environ. Microbiol. 2002, 68, 2214-2228.

(4) Sato, Y.; Bourne, D. G.; Willis, B. L. Coral Reefs 2011, 30, 753761.

(5) Richardson, L. L.; Stanic, D.; May, A.; Brownell, A.; Guntar, M.; Campagna, B. R. Life 2014, 4, 968-987.

(6) Casamatta, D.; Stanic, D.; Gantar, M.; Richardson, L. L. Phycologia 2012, 51, 489-499.

(7) Miller, A. W.; Richardson, L. L.FEMS Microbiol. Ecol. 2011, 75, 231-241.

(8) Meyer, J. L.; Gunasekera, S. P.; Scott, R. M.; Paul, V. J.; Teplitski, M. ISME J. 2016, 10, 1204-1216.

(9) Cardellina, J.; Dalietos, D.; Marner, F.; Mynderse, J.; Moore, R. Phytochemistry 1978, 17, 2091-2095.

(10) Gunasekera, S. P.; Ritson-Williams, R.; Paul, V. J. J. Nat. Prod. 2008, 71, 2060-2063.

(11) Meyer, J. L.; Paul, V. J.; Raymundo, L. J.; Teplitski, M. Front. Microbiol. 2017, 8, 618.

(12) Markowitz, V. M.; Korzeniewski, F.; Palaniappan, K.; Szeto, E.; Werner, G.; Padki, A. Nucleic Acids Res. 2006, 34, D344-D348.

(13) Buerger, P.; Wood-Charlson, E. M.; Weynberg, K. D.; Willis, B. L.; van Oppen, M. J. H. Front. Microbiol. 2016, 7, 2077.

(14) Armoza-Zvuloni, R.; Shaked, Y. Biogeosciences 2014, 11, 45874598.

(15) Rasher, D. B.; Hay, M. E. Proc. Natl. Acad. Sci. U. S. A. 2010, 107, 9683-9688.

(16) Richardson, L. L. FEMS Microbiol. Lett. 2007, 272, 182-187.

(17) Gantar, M.; Sekar, R.; Richardson, L. L. Microb. Ecol. 2009, 58, $856-864$

(18) Lesser, M. P. Coral Reefs 1997, 16, 187-192.

(19) Lesser, M. P. Annu. Rev. Physiol. 2006, 68, 253-278.

(20) Ross, C.; Fogarty, N. D.; Ritson-Williams, R.; Paul, V. J. Biol. Bull. 2017, 233, 206-218.

(21) Armoza-Zvuloni, R.; Schneider, A.; Shaked, Y. Front. Mar. Sci. 2016, 3, 21000.

(22) Leão, P. N.; Engene, N.; Antunes, A.; Gerwick, W. H.; Vasconcelos, V. Nat. Prod. Rep. 2012, 29, 372-391.

(23) Capper, A.; Erickson, A. A.; Ritson-Williams, R.; Becerro, M. A.; Arthur, K. A.; Paul, V. J. J. Exp. Mar. Biol. Ecol. 2016, 474, 100108.

(24) Sneed, J. M.; Meickle, T.; Engene, N.; Reed, S.; Gunasekera, S.; Paul, V. J. Harmful Algae 2017, 69, 75-82.

(25) Nübel, U.; Garcia-Pichel, F.; Muyzer, G. Appl. Environ. Microb. 1997, 63, 3327-3332.

(26) Weber, T.; Blin, K.; Srikanth Duddela, S.; Krug, D.; Kim, H. U. H.; Robert Bruccoleri, R.; Lee, S. Y.; Fischbach, M. A.; Müller, R.; Wohlleben, W.; Breitling, R.; Eriko Takano, E.; Medema, M. H. Nucleic Acids Res. 2015, 43, W237-W243. 
(27) Waterhouse, A. M.; Procter, J. B.; Martin, D. M. A.; Clamp, M.; Barton, G. J. Bioinformatics 2009, 25, 1189-1191.

(28) Rottig, M.; Medema, M. H.; Blin, K.; Weber, T.; Rausch, C.; Kohlbacher, O. Nucleic Acids Res. 2011, 39, W362-W367. 